\title{
Magnetic Exchange Coupling Through the Nonalternant Cyclopentadienyl $\pi$-System of Ferrocene
}

\author{
Patrick Hewitt, ${ }^{1}$ David A. Shultz, ${ }^{1 *}$ and Martin L. Kirk ${ }^{2 *}$ \\ ${ }^{1}$ Department of Chemistry, North Carolina State University, Raleigh, North Carolina 27695-8204. \\ ${ }^{2}$ Department of Chemistry, The University of New Mexico, MSC03 2060, 1 University of New Mexico, \\ Albuquerque, New Mexico 87131-0001.
}

Email: shultz@ncsu.edu; mkirk@unm.edu

\section{TABLE OF CONTENTS}

Materials and Methods

Synthesis

X-Ray Diffraction

Electronic Absorption Spectroscopy

Electrochemistry

EPR Spectroscopy

Magnetic Susceptibility

IR Spectra

Magnetic Susceptibility

Mass Spectrometry

\section{Materials and Methods}

Reagents and solvents were used as received and purchased from commercial vendors. Microwave reactions were performed on a CEM Discover System Model No. 908005. ${ }^{1} \mathrm{H}$ and ${ }^{13} \mathrm{C}$ NMR spectra were recorded on a Varian Mercury $400 \mathrm{MHz}$ or a Bruker NEO $400 \mathrm{MHz}$ spectrometer at room temperature. ${ }^{1} \mathrm{H}$ and ${ }^{13} \mathrm{C}$ chemical shifts are listed in parts per million (ppm) and are referenced to residual protons or carbons of the deuterated solvents, respectively. Infrared spectra were recorded on a Bruker Vertex 80v spectrometer with Bruker Platinum ATR attachment. Elemental analyses were performed by Atlantic Microlabs, Inc. Mass spectra were obtained either at the NCSU Mass Spectrometry Facility with is part of the Molecular Education, Technology and Research Innovation Center (METRIC) at NC State University, which is supported by the State of North Carolina or Michigan State University Mass Spectrometry and Metabolomics Core facility. Compounds $\mathrm{MOM}_{2} \mathrm{CATBpin},{ }^{1} \mathrm{Tp}^{\mathrm{Cum}, \mathrm{Me}} \mathrm{Zn}(\mathrm{OH}),{ }^{2} 1$ iodoferrocene, ${ }^{3} 1,1^{\prime}$-diiodoferrocene, ${ }^{3,4}$ and 1,3-diiodoferrocene ${ }^{5}$ were prepared as previously reported. 


\section{References}

1) Shultz, D. A.; Hollomon, M. G., "Preparation and EPR Spectroscopic Investigation of Conjugated Oligomers Containing Semiquinone Repeat Units," Chem. Mater. 2000, 12, 580-585.

2) Ruf, M.; Vahrenkamp, H., "Small Molecule Chemistry of the Pyrazolylborate-Zinc Unit TpCum,MeZn," Inorg. Chem. 1996, 35, 6571-6578.

3) Butler, I. R.; Wilkes, S. B.; McDonald, S. J.; Hobson, L. J.; Taralp, A.; Wilde, C. P. "A Convenient Preparation of lodoferrocenes,' Polyhedron 1993, 12, 129-131.

4) Khobragade, D. A.; Mahamulkar, S. G.; Pospíšil, L.; Císařová, I.; Rulíšek, L.; Jahn, U. "Acceptor-Substituted Ferrocenium Salts as Strong, Single-Electron Oxidants:

Synthesis, Electrochemistry, Theoretical Investigations, and Initial Synthetic Application," Chem. Eur. J. 2012, 18, $12267-12277$.

5) Zirakzadeh, A.; Herlein, A.; Groß, M. A.; Mereiter, K.; Wang, Y.; Weissensteiner, W.Halide-Mediated Ortho-Deprotonation Reactions Applied to the Synthesis of 1,2- and 1,3-Disubstituted Ferrocene Derivatives," Organometallics 2015, 34, 3820-3832.

\section{Synthesis}

1,1'- Bis(3"-(tert-butyl)-4",5"-bis(methoxymethoxy)phenyl)ferrocene (1,1'-(MOM $\left.\left.{ }_{2} \mathrm{Cat}\right)_{2} \mathrm{Fc}\right)$. To a $50 \mathrm{~mL}$ round-bottom flask, equipped with magnetic stir bar, was added 1,1'diiodoferrocene $(0.254 \mathrm{~g}, 0.580 \mathrm{mmol})$ of, $\mathrm{MOM}_{2}$ CatBpin $(0.441 \mathrm{~g}, 1.16 \mathrm{mmol}), \mathrm{Na}_{2} \mathrm{CO}_{3}(0.162 \mathrm{~g}$, $1.53 \mathrm{~mol})$ and $1.2 \mathrm{mg}(0.0053 \mathrm{mmol})$ of $\mathrm{Pd}(\mathrm{OAc})_{2}$. The flask was purge-pumped three times and backfilled with nitrogen, then $10 \mathrm{~mL}$ of THF and $3 \mathrm{~mL}$ of $\mathrm{H}_{2} \mathrm{O}$ were added. A nitrogen-purged reflux condenser was attached and the contents were heated to $60{ }^{\circ} \mathrm{C}$ in an oil bath for $18 \mathrm{~h}$ with stirring. The reaction was cooled to room temperature, transferred to a separatory funnel, washed with ca. $20 \mathrm{~mL}$ of brine and extracted with ca. $20 \mathrm{~mL}$ of EtOAc. The organic layer was separated, dried with $\mathrm{MgSO}_{4}$ and concentrated under reduced pressure. The residue was purified by flash chromatography (deactivated silica gel) with $20 \%$ ethyl acetate/hexanes to give the product $(259 \mathrm{mg}, 65 \%)$ as an orange-red oil. ${ }^{1} \mathrm{H} \mathrm{NMR}\left(400 \mathrm{MHz}, \mathrm{CDCl}_{3}\right) \delta=7.01-6.87$ $(\mathrm{m}, 4 \mathrm{H}), 5.20(\mathrm{~s}, 4 \mathrm{H}), 5.15(\mathrm{~s}, 4 \mathrm{H}), 4.78-4.49(\mathrm{~m}, 4 \mathrm{H}), 4.48-4.20(\mathrm{~m}, 4 \mathrm{H}), 3.66(\mathrm{~s}, 6 \mathrm{H}), 3.52$ $(\mathrm{s}, 6 \mathrm{H}), 1.41(\mathrm{~s}, 18 \mathrm{H}) .{ }^{13} \mathrm{C} \mathrm{NMR}\left(101 \mathrm{MHz}, \mathrm{CDCl}_{3}\right) \delta=149.8,144.2,142.9,133.5,118.8,113.1$, 98.8, 95.3, 87.3, 70.6, 68.2, 57.4, 56.2, 35.0, 30.5, 24.8. HRMS (TOF-APCl+) m/z: [M] ${ }^{+}$Calculated for $\mathrm{C}_{38} \mathrm{H}_{50} \mathrm{O}_{8} \mathrm{Fe}$ 688.2890; Found 688.2902.

1,1'-SQ ${ }_{2}$ Fc. 1,1'-(MOM ${ }_{2}$ Cat $)_{2}$ Fc (150 mg, $\left.0.217 \mathrm{mmol}\right)$ was added to a microwave vial with 3 $\mathrm{mL}$ of $\mathrm{MeOH}$ and 1 drop of $2 \mathrm{M} \mathrm{HCl}$, purged with nitrogen for 20 minutes, sealed, and heated in the microwave for $5 \mathrm{~min}$ at $90^{\circ} \mathrm{C}$ ( 35 Watt maximum power). The reaction was then transferred to a separatory funnel, washed with brine and extracted with $50 / 50 \mathrm{Et}_{2} \mathrm{O} /$ hexanes. The organic layer was then washed with saturated $\mathrm{NaHCO}_{3}$ solution, separated, dried with $\mathrm{MgSO}_{4}$ and concentrated under reduced pressure. To this residue was added $\mathrm{Zn}(\mathrm{OH}) \mathrm{Tp}{ }^{\mathrm{Cum}, \mathrm{Me}}$ (300 mg, $0.434 \mathrm{mmol}$ ) and $\mathrm{K}_{2} \mathrm{CO}_{3}(62 \mathrm{mg}, 0.449 \mathrm{mmol}$ ) and the flask was purge-pumped with nitrogen three times. $\mathrm{CH}_{2} \mathrm{Cl}_{2}(5 \mathrm{~mL})$ and $5 \mathrm{~mL}$ of $\mathrm{MeOH}$ were added and the contents were stirred under nitrogen for $1 \mathrm{~h}$, then the septum was removed and the flask was stirred in open air for $16 \mathrm{~h}$. The precipitate was filtered and then collected with $\mathrm{CH}_{2} \mathrm{Cl}_{2}$ to give a dark violet solid (293 mg, 
73\%). X-ray quality crystals were grown from $\mathrm{CH}_{2} \mathrm{Cl}_{2} / \mathrm{MeOH}$ slow evaporation. IR (solid) $v\left(\mathrm{~cm}^{-1}\right)$ : $2550(\mathrm{w},-\mathrm{BH})$. HRMS (TOF-APCl+) m/z: $[\mathrm{M}+\mathrm{H}]^{+}$Calculated for $\mathrm{C}_{108} \mathrm{H}_{123} \mathrm{~B}_{2} \mathrm{~N}_{12} \mathrm{O}_{4} \mathrm{FeZn} 2$ 1853.8028; Found 1853.7966.

\section{1,3- Bis(3'-(tert-butyl)-4',5'-bis(methoxymethoxy)phenyl)ferrocene (1,3-(MOM$\left.\left.{ }_{2} \mathrm{Cat}\right){ }_{2} \mathrm{Fc}\right)$.} To a $25 \mathrm{~mL}$ round-bottom flask, equipped with magnetic stir bar, was added 1,3diiodoferrocene ( $70 \mathrm{mg}, 0.160 \mathrm{mmol}$ ), $\mathrm{MOM}{ }_{2}$ CatBpin (122 mg, $0.321 \mathrm{mmol}$ ), $\mathrm{Na}_{2} \mathrm{CO}_{3}(54 \mathrm{mg}$, $0.51 \mathrm{mmol})$ and $\mathrm{Pd}(\mathrm{OAc})_{2}(1 \mathrm{mg}, 0.004 \mathrm{mmol})$. The flask was purge-pumped three times and backfilled with nitrogen, then $10 \mathrm{~mL}$ of THF and $3 \mathrm{~mL}$ of $\mathrm{H}_{2} \mathrm{O}$ were added. A nitrogen-purged reflux condenser was attached and the contents were heated to $60^{\circ} \mathrm{C}$ in an oil bath for $18 \mathrm{~h}$ with stirring. The reaction was cooled to room temperature, transferred to a separatory funnel, washed with ca. $20 \mathrm{~mL}$ of brine and extracted with ca. $20 \mathrm{~mL}$ of EtOAc. The organic layer was separated, dried with $\mathrm{MgSO}_{4}$ and concentrated under reduced pressure. The residue was purified by flash chromatography (deactivated silica gel) with $10 \%$ ethyl acetate/hexanes to give the product $(103 \mathrm{mg}, 93 \%)$ as an orange-red oil. ${ }^{1} \mathrm{H} \mathrm{NMR}\left(400 \mathrm{MHz}, \mathrm{CDCl}_{3}\right) \delta=7.23(\mathrm{~d}, \mathrm{~J}=$ $1.5 \mathrm{~Hz}, 2$ H), 7.19 (d, J = 1.5 Hz, 2 H), 5.26 (br. s., 4 H), 5.25 (br. s., 4 H), 4.92 (s, 1 H), 4.67 (s, 2 H), $3.99(\mathrm{~s}, 5 \mathrm{H}), 3.69(\mathrm{~s}, 6 \mathrm{H}), 3.58(\mathrm{~s}, 6 \mathrm{H}), 1.50(\mathrm{~s}, 18 \mathrm{H}) .{ }^{13} \mathrm{C} \mathrm{NMR}\left(101 \mathrm{MHz}, \mathrm{CDCl}_{3}\right) \delta=149.9$, 144.3, 143.0, 133.7, 119.0, 113.3, 98.9, 95.4, 87.4, 71.1, 67.4, 65.8, 57.5, 56.2, 35.1, 30.6. HRMS (TOF-APCl+) m/z: [M+H] ${ }^{+}$Calculated for $\mathrm{C}_{38} \mathrm{H}_{50} \mathrm{O}_{8} \mathrm{Fe}$ 689.2980; Found 689.2969.

1,3-SQ ${ }_{2}$ Fc. 1,3-( $\mathrm{MOM}_{2} \mathrm{Cat}_{2}{ }_{2} \mathrm{Fc}$ (49 $\left.\mathrm{mg}, 0.071 \mathrm{mmol}\right)$ was added to a microwave vial with 3 $\mathrm{mL}$ of $\mathrm{MeOH}$ and 1 drop of $2 \mathrm{M} \mathrm{HCl}$, purged with nitrogen for 20 minutes, sealed, and heated in the microwave for $5 \mathrm{~min}$ at $90^{\circ} \mathrm{C}$ ( 35 Watt maximum power). The reaction was then transferred to a separatory funnel, washed with brine and extracted with $50 / 50 \mathrm{Et}_{2} \mathrm{O} /$ hexanes. The organic layer was then washed with saturated $\mathrm{NaHCO}_{3}$ solution, separated, dried with $\mathrm{MgSO}_{4}$ and concentrated under reduced pressure. To this residue was added $\mathrm{Zn}(\mathrm{OH}) \mathrm{Tp}{ }^{\mathrm{Cum}, \mathrm{Me}}(97 \mathrm{mg}, 0.140$ $\mathrm{mmol})$ and $\mathrm{K}_{2} \mathrm{CO}_{3}(19 \mathrm{mg}, 0.137 \mathrm{mmol})$ and the flask was purge-pumped with nitrogen three times. $5 \mathrm{~mL}$ of $\mathrm{CH}_{2} \mathrm{Cl}_{2}$ and $5 \mathrm{~mL}$ of $\mathrm{MeOH}$ were added and the contents were stirred under nitrogen for $1 \mathrm{~h}$, then the septum was removed and the flask was stirred in open air for $16 \mathrm{~h}$. The precipitate was filtered and then collected with $\mathrm{CH}_{2} \mathrm{Cl}_{2}$ to give a dark violet solid (93 mg, 71\%). X-ray quality crystals were grown from $\mathrm{CH}_{2} \mathrm{Cl}_{2} /$ EtOH slow evaporation. IR (solid) $v\left(\mathrm{~cm}^{-1}\right)$ : $2550(\mathrm{w},-\mathrm{BH})$. HRMS (TOF-APCl+) m/z: $[\mathrm{M}+\mathrm{H}]^{+}$Calculated for $\mathrm{C}_{108} \mathrm{H}_{123} \mathrm{~B}_{2} \mathrm{~N}_{12} \mathrm{O}_{4} \mathrm{FeZn} \mathrm{n}_{2}$ 1853.8028; Found 1853.7979.

1-(3'-(tert-Butyl)-4',5'-bis(methoxymethoxy)phenyl)ferrocene (1-MOM ${ }_{2}$ CatFc). To a $25 \mathrm{~mL}$ round-bottom flask, equipped with magnetic stir bar, was added 1-iodoferrocene (120 mg, $0.385 \mathrm{mmol}$ ), $\mathrm{MOM}_{2}$ CatBpin (146 mg, $0.384 \mathrm{mmol}$ ), $\mathrm{Na}_{2} \mathrm{CO}_{3}(61 \mathrm{mg}, 0.58 \mathrm{mmol}$ ) and Pd(OAc) 2 ( $1 \mathrm{mg}, 0.004 \mathrm{mmol}$ ). The flask was purge-pumped three times and backfilled with nitrogen, then $10 \mathrm{~mL}$ of THF and $3 \mathrm{~mL}$ of $\mathrm{H}_{2} \mathrm{O}$ were added. A nitrogen-purged reflux condenser was attached and the contents were heated to $60^{\circ} \mathrm{C}$ in an oil bath for $18 \mathrm{~h}$ with stirring. The reaction was cooled to room temperature, transferred to a separatory funnel, washed with ca. $20 \mathrm{~mL}$ of brine and extracted with ca. $20 \mathrm{~mL}$ of EtOAc. The organic layer was separated, dried with $\mathrm{MgSO}_{4}$ and concentrated under reduced pressure. The residue was purified by flash chromatography (deactivated silica gel) with $5 \%$ ethyl acetate/hexanes to give the product (129 $\mathrm{mg}, 76 \%)$ as an orange-red oil. ${ }^{1} \mathrm{H} \mathrm{NMR}\left(400 \mathrm{MHz}, \mathrm{CDCl}_{3}\right) \delta=7.18(\mathrm{~d}, J=2.0 \mathrm{~Hz}, 1 \mathrm{H}), 7.13(\mathrm{~d}, J=$ $2.0 \mathrm{~Hz}, 1 \mathrm{H}), 5.22(\mathrm{~s}, 4 \mathrm{H}), 4.55(\mathrm{t}, J=1.8 \mathrm{~Hz}, 2 \mathrm{H}), 4.27(\mathrm{t}, J=1.8 \mathrm{~Hz}, 2 \mathrm{H}), 4.07(\mathrm{~s}, 5 \mathrm{H}), 3.68(\mathrm{~s}, 3$ $\mathrm{H}), 3.56(\mathrm{~s}, 3 \mathrm{H}), 1.47(\mathrm{~s}, 9 \mathrm{H}) .{ }^{13} \mathrm{C} N M R\left(151 \mathrm{MHz} \mathrm{CDCl}_{3}\right) \delta=149.9,144.2,142.9,133.9,118.9$, 
113.3, 98.9, 95.5, 86.8, 69.5, 68.5, 66.9, 57.5, 56.2, 35.1, 30.6. HRMS (TOF-APCI+) m/z: [M]+ Calculated for $\mathrm{C}_{24} \mathrm{H}_{30} \mathrm{O}_{4} \mathrm{Fe} 436.1540$; Found 436.1532.

1-SQFc. 1-MOM ${ }_{2}$ CatFc (108 mg, $0.246 \mathrm{mmol}$ ) of was dissolved in $3 \mathrm{~mL}$ of $\mathrm{MeOH}$ with 2 drops of $2 \mathrm{M} \mathrm{HCl}$ in a microwave vial, sealed, and heated in the microwave for $5 \mathrm{~min}$ at $90{ }^{\circ} \mathrm{C}(30 \mathrm{Watts}$ maximum power). Reaction was transferred to a separatory funnel, washed with brine and extracted with $\mathrm{Et}_{2} \mathrm{O}$. The organic layer was separated and dried with $\mathrm{MgSO}_{4}$ and concentrated. To the orange residue in a $50 \mathrm{~mL}$ round-bottom flask with a magnetic stir bar was added $\mathrm{Zn}(\mathrm{OH}) \mathrm{Tp}^{\mathrm{Cum}, \mathrm{Me}}(171 \mathrm{mg}, 0.247 \mathrm{mmol})$ and $\mathrm{KOH}(14 \mathrm{mg}, 0.249 \mathrm{mmol})$. The flask was purgepumped three times with nitrogen and then $5 \mathrm{~mL}$ each of anhydrous, deoxygenated $\mathrm{CH}_{2} \mathrm{Cl}_{2}$ and $\mathrm{MeOH}$ was added. The reaction was stirred for $1 \mathrm{~h}$ under nitrogen and then opened to air and stirred for $16 \mathrm{~h}$. The precipitate was filtered and then collected with $\mathrm{CH}_{2} \mathrm{Cl}_{2}$ to give a dark violet solid (293 mg, 73\%). X-ray quality crystals were grown from $\mathrm{CH}_{2} \mathrm{Cl}_{2} / \mathrm{EtOH}$ slow evaporation. IR (solid) v (cm-1): $2550(\mathrm{w},-\mathrm{BH})$. HRMS (TOF-APCl+) m/z: [M] ${ }^{+}$Calculated for $\mathrm{C}_{59} \mathrm{H}_{67} \mathrm{BN}_{6} \mathrm{O}_{2} \mathrm{FeZn}$ 1019.4142; Found 1019.4115.

\section{X-Ray Diffraction}

1,3-SQ $\mathbf{Z}_{2}$ Fc. A dark green block-like specimen of $\mathrm{C}_{110.91} \mathrm{H}_{126.81} \mathrm{~B}_{2} \mathrm{Cl}_{5.81} \mathrm{FeN}_{12} \mathrm{O}_{4} \mathrm{Zn}_{2}$, approximate dimensions $0.216 \mathrm{~mm} \times 0.321 \mathrm{~mm} \times 0.563 \mathrm{~mm}$, was used for the X-ray crystallographic analysis (rds940). The X-ray intensity data were measured on a Bruker-Nonius X8 Kappa APEX II Kgeometry diffractometer system equipped with a fine-focus sealed tube (MoK $\alpha, \lambda=0.71073$ Å) and a graphite monochromator.

The integration of the data using a triclinic unit cell yielded a total of 148235 reflections to a maximum $\theta$ angle of $27.93^{\circ}$ ( $0.76 \AA$ resolution), of which 27074 were independent (average redundancy 5.475 , completeness $\left.=98.8 \%, R_{\text {int }}=3.46 \%, R_{\text {sig }}=3.11 \%\right)$ and $20241(74.76 \%)$ were greater than $2 \sigma\left(\mathrm{F}^{2}\right)$. The final cell constants of $\underline{a}=14.3395(12) \AA, \underline{b}=18.2664(15) \AA, \underline{c}=23.2786(19) \AA, \alpha=71.655(2)^{\circ}, \beta=80.662(2)^{\circ}, \gamma$ $=86.188(2)^{\circ}$, volume $=5710.0(8) \AA^{3}$, are based upon the refinement of the XYZ-centroids of 9823 reflections above $20 \sigma(\mathrm{I})$ with $4.316^{\circ}<2 \theta<55.12^{\circ}$. Data were corrected for absorption effects using the numerical method (SADABS). The ratio of minimum to maximum apparent transmission was 0.838 . The calculated minimum and maximum transmission coefficients (based on crystal size) are 0.6840 and 0.8580 .

The structure was solved and refined using the Bruker SHELXTL Software Package, using the space group $P-1$, with $Z=2$ for the formula unit, $\mathrm{C}_{110.91} \mathrm{H}_{126.81} \mathrm{~B}_{2} \mathrm{Cl}_{5.81} \mathrm{FeN}_{12} \mathrm{O}_{4} \mathrm{Zn}_{2}$. The final anisotropic full-matrix least-squares refinement on $\mathrm{F}^{2}$ with 1402 variables converged at $\mathrm{R} 1$ $=5.94 \%$, for the observed data and $w R 2=17.82 \%$ for all data. The goodness-of-fit was 1.045 . The largest peak in the final difference electron density synthesis was $1.802 \mathrm{e}^{-} / \AA^{3}$ and the largest hole was $-1.736 \mathrm{e}^{-} / \AA^{3}$ with an RMS deviation of $0.089 \mathrm{e}^{-} / \AA^{3}$. On the basis of the final model, the calculated density was $1.225 \mathrm{~g} / \mathrm{cm}^{3}$ and $F(000), 2206 \mathrm{e}^{-}$.

Table S3. Sample and crystal data for rds940 (1,3-SQ 2 Fc).

Identification code
Chemical formula

Formula weight

\section{rds940}

$\mathrm{C}_{110.91} \mathrm{H}_{126.81} \mathrm{~B}_{2} \mathrm{Cl}_{5.81} \mathrm{FeN}_{12} \mathrm{O}_{4} \mathrm{Zn}_{2}$

$2106.24 \mathrm{~g} / \mathrm{mol}$ 


\begin{tabular}{|l|l|l|}
\hline Temperature & $100(2) \mathrm{K}$ & \multicolumn{2}{|l|}{} \\
\hline Wavelength & $0.71073 \AA$ & \\
\hline Crystal size & $0.216 \times 0.321 \times 0.563 \mathrm{~mm}$ & \\
\hline Crystal habit & dark green block & \\
\hline Crystal system & triclinic & \multicolumn{2}{l|}{} \\
\hline Space group & $\mathrm{P}-1$ & $\alpha=71.655(2)^{\circ}$ \\
\hline Unit cell dimensions & $\mathrm{a}=14.3395(12) \AA$ & $\beta=80.662(2)^{\circ}$ \\
\hline & $\mathrm{b}=18.2664(15) \AA$ & $\mathrm{\gamma}=86.188(2)^{\circ}$ \\
\hline & $\mathrm{c}=23.2786(19) \AA$ & \\
\hline Volume & $5710.0(8) \AA^{3}$ & \\
\hline Z & 2 & \\
\hline Density (calculated) & $1.225 \mathrm{~g} / \mathrm{cm}^{3}$ & \\
\hline Absorption coefficient & $0.732 \mathrm{~mm}^{-1}$ & \\
\hline F(000) & 2206 & \\
\hline & & \\
\hline
\end{tabular}

Table S4. Data collection and structure refinement for $\mathrm{rds} 940\left(\mathbf{1}, \mathbf{3}-\mathrm{SQ}_{\mathbf{2}} \mathrm{Fc}\right)$.

\begin{tabular}{|c|c|c|}
\hline Diffractometer & \multicolumn{2}{|c|}{ Bruker-Nonius X8 Kappa APEX II k-geometry diffractometer } \\
\hline Radiation source & \multicolumn{2}{|c|}{ fine-focus sealed tube (MoK $\alpha, \lambda=0.71073 \AA$ ) } \\
\hline Theta range for data collection & \multicolumn{2}{|c|}{1.71 to $27.93^{\circ}$} \\
\hline Index ranges & \multicolumn{2}{|c|}{$-18<=\mathrm{h}<=18,-23<=\mathrm{k}<=24,-30<=\mid<=30$} \\
\hline Reflections collected & \multicolumn{2}{|l|}{148235} \\
\hline Independent reflections & \multicolumn{2}{|c|}{$27074[\mathrm{R}$ (int) $=0.0346]$} \\
\hline $\begin{array}{l}\text { Coverage of independent } \\
\text { reflections }\end{array}$ & \multicolumn{2}{|l|}{$98.8 \%$} \\
\hline Absorption correction & \multicolumn{2}{|l|}{ numerical } \\
\hline Max. and min. transmission & \multicolumn{2}{|l|}{0.8580 and 0.6840} \\
\hline Structure solution technique & \multicolumn{2}{|l|}{ direct methods } \\
\hline Structure solution program & \multicolumn{2}{|c|}{ XT, VERSION 2014/5 (Sheldrick, 2015) } \\
\hline Refinement method & \multicolumn{2}{|c|}{ Full-matrix least-squares on $\mathrm{F}^{2}$} \\
\hline Refinement program & \multicolumn{2}{|c|}{ SHELXL-2018/3 (Sheldrick, 2015) } \\
\hline Function minimized & \multicolumn{2}{|c|}{$\Sigma w\left(F_{o}^{2}-F_{c}^{2}\right)^{2}$} \\
\hline Data / restraints / parameters & \multicolumn{2}{|l|}{27074 / 2132 / 1402} \\
\hline Goodness-of-fit on $F^{2}$ & \multicolumn{2}{|l|}{1.045} \\
\hline$\Delta / \sigma_{\max }$ & \multicolumn{2}{|l|}{0.001} \\
\hline \multirow[t]{2}{*}{ Final $\mathbf{R}$ indices } & 20241 data; $I>2 \sigma(I)$ & $R 1=0.0594, w R 2=0.1605$ \\
\hline & all data & $\mathrm{R} 1=0.0844, \mathrm{wR} 2=0.1782$ \\
\hline Weighting scheme & \multicolumn{2}{|c|}{$\begin{array}{l}w=1 /\left[\sigma^{2}\left(F_{o}^{2}\right)+(0.0843 P)^{2}+10.9918 P\right] \\
\text { where } P=\left(F_{o}^{2}+2 F_{c}^{2}\right) / 3\end{array}$} \\
\hline Largest diff. peak and hole & \multicolumn{2}{|c|}{1.802 and $-1.736 \mathrm{e}^{-3}$} \\
\hline R.M.S. deviation from mean & \multicolumn{2}{|l|}{$0.089 \mathrm{e}^{-3}$} \\
\hline
\end{tabular}

1,1'-SQ $\mathbf{S}_{2}$ Fc. A dark green plate-like specimen of $\mathrm{C}_{112} \mathrm{H}_{130} \mathrm{~B}_{2} \mathrm{Cl}_{8} \mathrm{FeN}_{12} \mathrm{O}_{4} \mathrm{Zn}_{2}$, approximate dimensions $0.120 \mathrm{~mm} \times 0.275 \mathrm{~mm} \times 0.378 \mathrm{~mm}$, was used for the X-ray crystallographic analysis. The X-ray intensity data were measured on a Bruker-Nonius X8 Kappa APEX II 
system equipped with a fine-focus sealed tube (MoK $\alpha, \lambda=0.71073 \AA$ ) and a graphite monochromator.

A total of 1230 frames were collected. The total exposure time was 10.25 hours. The frames were integrated with the Bruker SAINT software package using a narrow-frame algorithm. The integration of the data using a monoclinic unit cell yielded a total of 120431 reflections to a maximum $\theta$ angle of $30.55^{\circ}$ ( $0.70 \AA$ resolution), of which 17092 were independent (average redundancy 7.046 , completeness $\left.=99.9 \%, R_{\text {int }}=4.77 \%, R_{\text {sig }}=3.43 \%\right)$ and $12955(75.80 \%)$ were greater than $2 \sigma\left(\mathrm{F}^{2}\right)$. The final cell constants

of $\underline{a}=12.1222(5) \AA ⿻$, $\underline{b}=17.8809(8) \AA, \underline{c}=25.7796(11) \AA, \beta=91.2515(15)^{\circ}$, volume $=5586.5(4) \AA^{3}$, are based upon the refinement of the XYZ-centroids of 1065 reflections above $20 \sigma(\mathrm{I})$ with $4.323^{\circ}<2 \theta<58.84^{\circ}$. Data were corrected for absorption effects using the Numerical Mu Calculated method (SADABS). The ratio of minimum to maximum apparent transmission was 0.825 . The calculated minimum and maximum transmission coefficients (based on crystal size) are 0.5954 and 0.7218 .

The structure was solved and refined using the Bruker SHELXTL Software Package, using the space group $P 121 / n 1$, with $Z=2$ for the formula unit, $\mathrm{C}_{112} \mathrm{H}_{130} \mathrm{~B}_{2} \mathrm{Cl}_{8} \mathrm{FeN}_{12} \mathrm{O}_{4} \mathrm{Zn}_{2}$. The final anisotropic full-matrix least-squares refinement on $\mathrm{F}^{2}$ with 649 variables converged at $\mathrm{R} 1$ $=5.58 \%$, for the observed data and $w R 2=15.27 \%$ for all data. The goodness-of-fit was 1.034 . The largest peak in the final difference electron density synthesis was $2.213 \mathrm{e}^{-} / \AA^{3}$ and the largest hole was $-1.519 \mathrm{e}^{-} / \AA^{3}$ with an RMS deviation of $0.094 \mathrm{e}^{-} / \AA^{3}$. On the basis of the final model, the calculated density was $1.308 \mathrm{~g} / \mathrm{cm}^{3}$ and $F(000), 2300 \mathrm{e}^{-}$.

Table S1. Sample and crystal data for rds927 (1,1'-SQ 2 Fc).

\begin{tabular}{|c|c|c|}
\hline Identification code & \multicolumn{2}{|c|}{ rds927 } \\
\hline Chemical formula & \multicolumn{2}{|c|}{$\mathrm{C}_{112} \mathrm{H}_{130} \mathrm{~B}_{2} \mathrm{Cl}_{8} \mathrm{FeN}_{12} \mathrm{O}_{4} \mathrm{Zn}_{2}$} \\
\hline Formula weight & \multicolumn{2}{|c|}{$2200.08 \mathrm{~g} / \mathrm{mol}$} \\
\hline Temperature & \multicolumn{2}{|l|}{$100(2) \mathrm{K}$} \\
\hline Wavelength & \multicolumn{2}{|l|}{$0.71073 \AA$} \\
\hline Crystal size & \multicolumn{2}{|c|}{$0.120 \times 0.275 \times 0.378 \mathrm{~mm}$} \\
\hline Crystal habit & \multicolumn{2}{|c|}{ dark green plate } \\
\hline Crystal system & \multicolumn{2}{|l|}{ monoclinic } \\
\hline Space group & \multicolumn{2}{|l|}{ P 1 21/n 1} \\
\hline \multirow[t]{3}{*}{ Unit cell dimensions } & $a=12.1222(5) \AA$ & $\alpha=90^{\circ}$ \\
\hline & $b=17.8809(8) \AA$ & $\beta=91.2515(15)^{\circ}$ \\
\hline & $c=25.7796(11) \AA$ & $\gamma=90^{\circ}$ \\
\hline Volume & $5586.5(4) \AA^{3}$ & \\
\hline $\mathbf{Z}$ & \multicolumn{2}{|l|}{2} \\
\hline Density (calculated) & \multicolumn{2}{|l|}{$1.308 \mathrm{~g} / \mathrm{cm}^{3}$} \\
\hline Absorption coefficient & \multicolumn{2}{|l|}{$0.801 \mathrm{~mm}^{-1}$} \\
\hline$F(000)$ & \multicolumn{2}{|l|}{2300} \\
\hline
\end{tabular}

Table S2. Data collection and structure refinement for rds927 (1,1'-SQ $\mathbf{2} \mathbf{F c})$.

\begin{tabular}{l|l}
\hline Diffractometer & Bruker-Nonius X8 Kappa APEX II \\
\hline Radiation source & fine-focus sealed tube (MoK $\alpha, \lambda=0.71073 \AA$ )
\end{tabular}




\begin{tabular}{|c|c|c|}
\hline Theta range for data collection & \multicolumn{2}{|l|}{1.39 to $30.55^{\circ}$} \\
\hline Index ranges & \multicolumn{2}{|c|}{$-17<=h<=17,-25<=k<=25,-36<=\mid<=33$} \\
\hline Reflections collected & \multicolumn{2}{|l|}{120431} \\
\hline Independent reflections & \multicolumn{2}{|c|}{$17092[\mathrm{R}$ (int) $=0.0477]$} \\
\hline Coverage of independent reflections & \multicolumn{2}{|l|}{$99.9 \%$} \\
\hline Absorption correction & \multicolumn{2}{|c|}{ Numerical Mu Calculated } \\
\hline Max. and min. transmission & \multicolumn{2}{|c|}{0.7218 and 0.5954} \\
\hline Structure solution technique & \multicolumn{2}{|l|}{ direct methods } \\
\hline Structure solution program & \multicolumn{2}{|l|}{ XT, VERSION 2014/5 } \\
\hline Refinement method & \multicolumn{2}{|c|}{ Full-matrix least-squares on $\mathrm{F}^{2}$} \\
\hline Refinement program & \multicolumn{2}{|c|}{ SHELXL-2018/3 (Sheldrick, 2018) } \\
\hline Function minimized & \multicolumn{2}{|c|}{$\Sigma w\left(F_{o}^{2}-F_{c}^{2}\right)^{2}$} \\
\hline Data / restraints / parameters & \multicolumn{2}{|l|}{$17092 / 0 / 649$} \\
\hline Goodness-of-fit on $F^{2}$ & \multicolumn{2}{|l|}{1.034} \\
\hline$\Delta / \sigma_{\max }$ & \multicolumn{2}{|l|}{0.001} \\
\hline \multirow[t]{2}{*}{ Final $\mathbf{R}$ indices } & 12955 data; $I>2 \sigma(I)$ & $R 1=0.0558, w R 2=0.1378$ \\
\hline & all data & $R 1=0.0804, w R 2=0.1527$ \\
\hline Weighting scheme & \multicolumn{2}{|c|}{$\begin{array}{l}w=1 /\left[\sigma^{2}\left(F_{o}^{2}\right)+(0.0643 P)^{2}+10.4261 P\right] \\
\text { where } P=\left(F_{o}^{2}+2 F_{c}^{2}\right) / 3\end{array}$} \\
\hline Largest diff. peak and hole & \multicolumn{2}{|c|}{2.213 and $-1.519 \mathrm{e}^{-3}$} \\
\hline R.M.S. deviation from mean & \multicolumn{2}{|l|}{$0.094 \mathrm{e}^{-3}$} \\
\hline
\end{tabular}

\section{References for X-ray Crystallography of 1,3-SQ 2 Fc and 1,1'-SQ ${ }_{2} \mathrm{Fc}$}

1) Bruker-AXS Inc. (2014), Madison Wisconsin, USA.

2) Sheldrick, G. M. (2008). Acta Cryst. A64, 112-122.

3) Dolomanov, O.V.; Bourhis, L.J.; Gildea, R.J.; Howard, J.A.K.; Puschmann, H., OLEX2: A complete structure solution, refinement and analysis program (2009). J. Appl. Cryst., 42, 339-341.

1-SQFC. X-ray diffraction data were measured on Bruker D8 Venture PHOTON II CPAD diffractometer equipped with a $\mathrm{CU}$ K $\alpha$ INCOATEC ImuS micro-focus source $(\lambda=1.54178 \AA$ A). Indexing was performed using APEX ${ }^{1}$ (Difference Vectors method). Data integration and reduction were performed using SaintPlus. ${ }^{2}$ Absorption correction was performed by multi-scan method implemented in SADABS. ${ }^{3}$ Space group was determined using XPREP implemented in APEX3 [1]. Structure(s) was (were) solved using SHELXT ${ }^{4}$ and refined using SHELXL-2018/35 (fullmatrix least-squares on F2) through OLEX2 interface program. ${ }^{6}$ Ellipsoid plot(s) was(were) drawn with Platon. ${ }^{7}$ Disordered ferrocene, $\mathrm{Ph}-\mathrm{CH}\left(\mathrm{CH}_{3}\right)_{2} /-\mathrm{CH}\left(\mathrm{CH}_{3}\right)_{2}$ groups and solvent molecules were refined with restraints. Due to disorder the amount of solvent is tentative. Crystal data and refinement conditions are shown in Table S5.

Table S5. Sample and crystal data for fcsq (1-SQFc).

\begin{tabular}{|l|l|}
\hline Identification code & $\mathrm{FCSQ}_{-}$ \\
\hline Empirical formula & $\mathrm{C}_{59.36} \mathrm{H}_{66.73} \mathrm{BCl}_{0.92} \mathrm{FeN}_{6} \mathrm{O}_{2} \mathrm{Zn}$ \\
\hline Moiety Formula & $\mathrm{C}_{59} \mathrm{H}_{66} \mathrm{BFeN}_{6} \mathrm{O}_{2} \mathrm{Zn}, 0.36\left(\mathrm{CH}_{2} \mathrm{Cl}_{2}\right), 0.19 \mathrm{Cl}$ (tentative, part of disordered $\left.\mathrm{CH}_{2} \mathrm{Cl}_{2}\right)$ \\
\hline Formula weight & 1060.85 \\
\hline
\end{tabular}




\begin{tabular}{|c|c|}
\hline Temperature/K & 296.65 \\
\hline Crystal system & triclinic \\
\hline Space group & P-1 \\
\hline $\mathrm{a} / \AA ̊$ & 13.1791(10) \\
\hline b/Å & $21.0759(16)$ \\
\hline$c / \AA ̊$ & $21.1546(16)$ \\
\hline$\alpha /^{\circ}$ & $79.432(4)$ \\
\hline$\beta /^{\circ}$ & $81.452(4)$ \\
\hline$\gamma / /^{\circ}$ & $88.723(4)$ \\
\hline Volume/ $/ \AA^{3}$ & $5712.0(8)$ \\
\hline Z & 4 \\
\hline$\rho_{\text {calc }} \mathrm{g} / \mathrm{cm}^{3}$ & 1.234 \\
\hline$\mu / \mathrm{mm}^{-1}$ & 3.297 \\
\hline$F(000)$ & 2230.0 \\
\hline Crystal size $/ \mathrm{mm}^{3}$ & $0.44 \times 0.33 \times 0.05$ \\
\hline Radiation & $\operatorname{CuK} \alpha(\lambda=1.54178)$ \\
\hline 20 range for data collection $/^{\circ}$ & 4.264 to 140.094 \\
\hline Index ranges & $-16 \leq h \leq 16,-25 \leq k \leq 23,-25 \leq 1 \leq 25$ \\
\hline Reflections collected & 102083 \\
\hline Independent reflections & $21485\left[R_{\text {int }}=0.0849, R_{\text {sigma }}=0.1077\right]$ \\
\hline Data/restraints/parameters & $21485 / 4064 / 1851$ \\
\hline Goodness-of-fit on $F^{2}$ & 1.026 \\
\hline Final $R$ indexes $[I>=2 \sigma(I)]$ & $R_{1}=0.0772, w R_{2}=0.2170$ \\
\hline Final R indexes [all data] & $\mathrm{R}_{1}=0.0985, \mathrm{wR}_{2}=0.2431$ \\
\hline Largest diff. peak/hole / e $\AA^{-3}$ & $0.41 /-0.88$ \\
\hline
\end{tabular}

\section{References for X-ray Crystallography of 1-SQFc}

1) Bruker (2019). APEX3. Bruker AXS LLC, Madison, Wisconsin, USA.

2) Bruker (2019) SAINT. Bruker AXS LLC, Madison, Wisconsin, USA.

3) Krause, L., Herbst-Irmer, R., Sheldrick, G. M., Stalke, D. "Comparison of silver and molybdenum microfocus X-ray sources for single-crystal structure determination," J. Appl. Cryst. 2015, 48, 310.

4) Sheldrick, G. M. "SHELXT - Integrated space-group and crystal-structure determination," Acta Cryst. 2015, A71, 3-8.

5) Sheldrick, G. M. "Crystal structure refinement with SHELXL", Acta Cryst. 2015, C71, 3-8

6) Dolomanov, O. V.; Bourhis, L. J.; Gildea, R .J.; Howard, J. A. K.; Puschmann, H. “OLEX2: A complete structure solution, refinement and analysis program," J. Appl. Cryst., 2009, 42, 339-341

7) Spek, A. L. "Structure validation in chemical crystallography," Acta Cryst. 2009, D65, 148-155. 


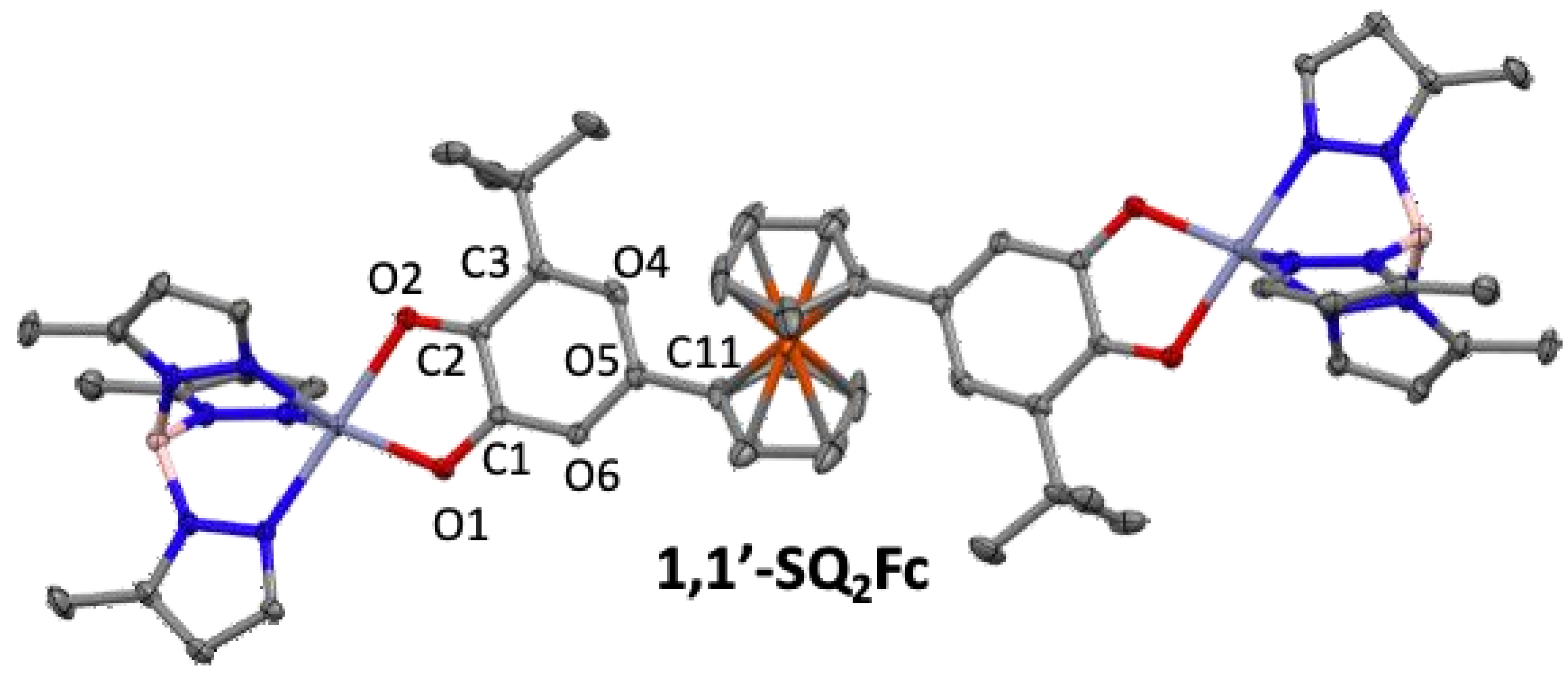

Figure S1. Thermal ellipsoid plots (50\%) and atomic numbering schemes for 1,1'-SQ $\mathbf{2} \mathbf{F c}$. Hydrogens and cumenyl groups are omitted for clarity. 1,1'$\mathbf{S Q}_{2} \mathbf{F c}$ has inversion symmetry, so only one SQ ring is labeled. 


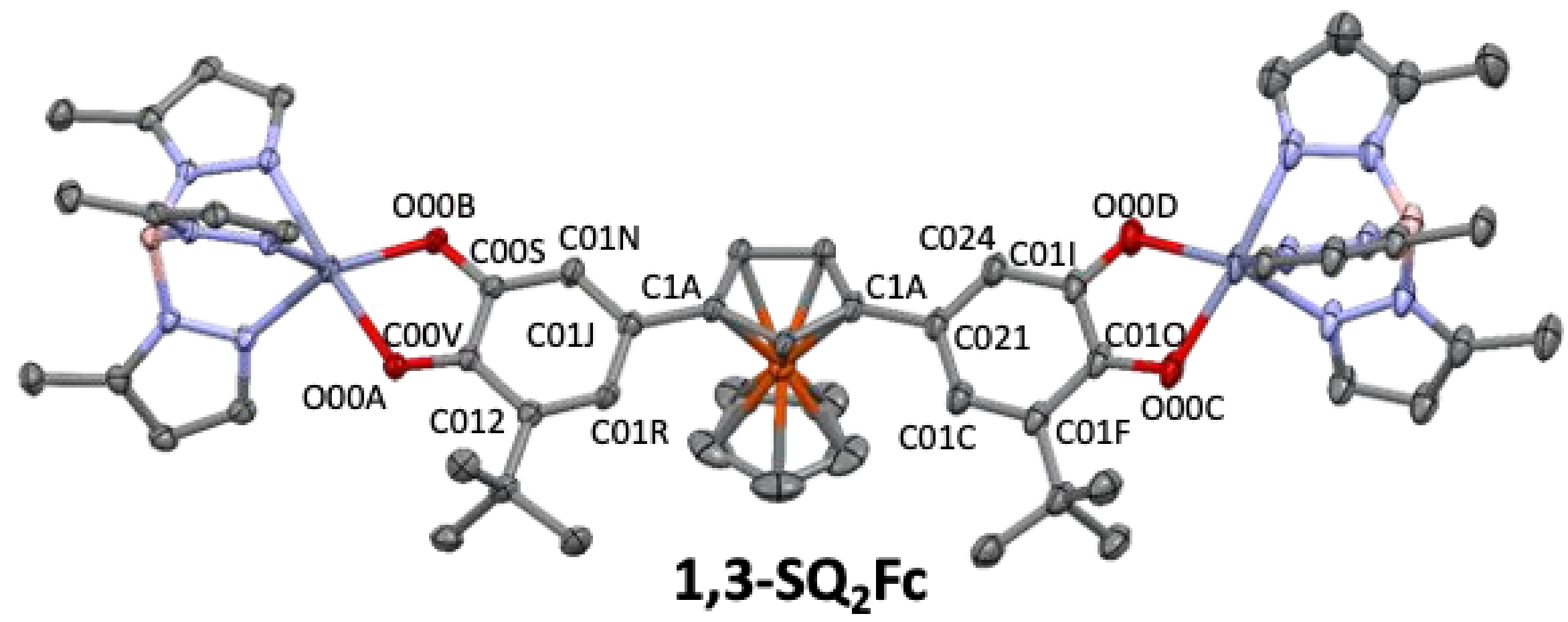

Figure S2. Thermal ellipsoid plots (50\%) and atomic numbering schemes for 1,3-SQ 2 Fc. Hydrogens and cumenyl groups are omitted for clarity. 


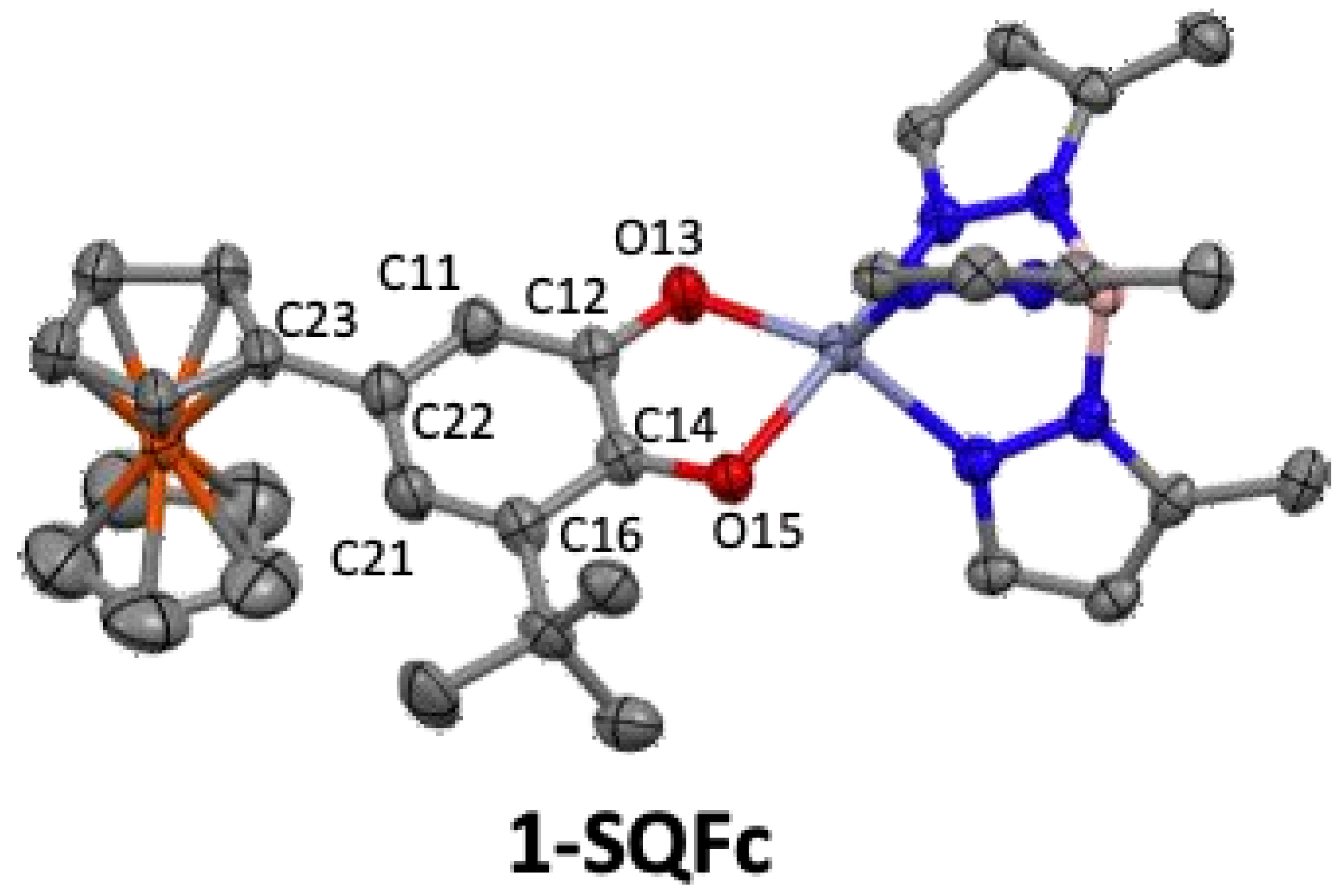

Figure S3. Thermal ellipsoid plots (50\%) and atomic numbering schemes for 1-SQ-Fc. Hydrogens and cumenyl groups are omitted for clarity. 
Electronic Absorption Spectroscopy. The absorption spectra were collected on a UV-3600 Shimadzu UV-Vis-NIR spectrometer as solutions in methylene chloride for $\mathbf{1}-\mathrm{SQFC}, \mathbf{1 , 1} \mathbf{1}^{\prime}-\mathbf{S Q}_{\mathbf{2}} \mathbf{F c}$ and $\mathbf{1 , 3 - S Q _ { 2 }} \mathbf{F c}$ and are shown in Figure S4A. The spectra for all three compounds have similar features; however, in accordance with the presence of two SQ chromophores, extinction

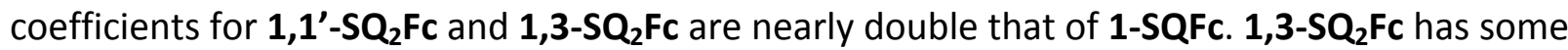
spectral features which differ from those of 1-SQFc than $\mathbf{1}, \mathbf{1}^{\prime}-\mathbf{S Q}_{\mathbf{2}} \mathbf{F c}$, such as the region near $13000-14000 \mathrm{~cm}^{-1}$. This band may have SQ $\left(\pi \rightarrow \pi^{*}\right)$ and/or Fc $\rightarrow$ SQ charge transfer band as suggested by the solvent dependence shown in Figure S2B (the more polar solvent (DMSO) shifts the absorption band to lower energy by nearly $\left.1000 \mathrm{~cm}^{-1}\right)$, as well as the $\mathrm{Fc} / \mathrm{Fc}^{+}$and SQ/CAT redox potentials (vide infra). Neither the band centered around $17500 \mathrm{~cm}^{-1}$ nor the band around $26000 \mathrm{~cm}^{-1}$ are ferrocene-only bands as the only bands in this region for ferrocene are at $22700 \mathrm{~cm}^{-1}$ and $30000 \mathrm{~cm}^{-1}$ with extinction coefficients of $95 \mathrm{M}^{-1} \mathrm{~cm}^{-1}$ and $54 \mathrm{M}^{-1} \mathrm{~cm}^{-1}$, respectively (Figure S4A inset). These are several orders of magnitude less than any of the bands observed in 1-SQFc, $\mathbf{1}, \mathbf{1}^{\prime}-\mathrm{SQ}_{2} \mathbf{F c}$ or $\mathbf{1 , 3 - S Q _ { 2 }} \mathbf{F c}$, consistent with the presence of strong SQFc electronic coupling.
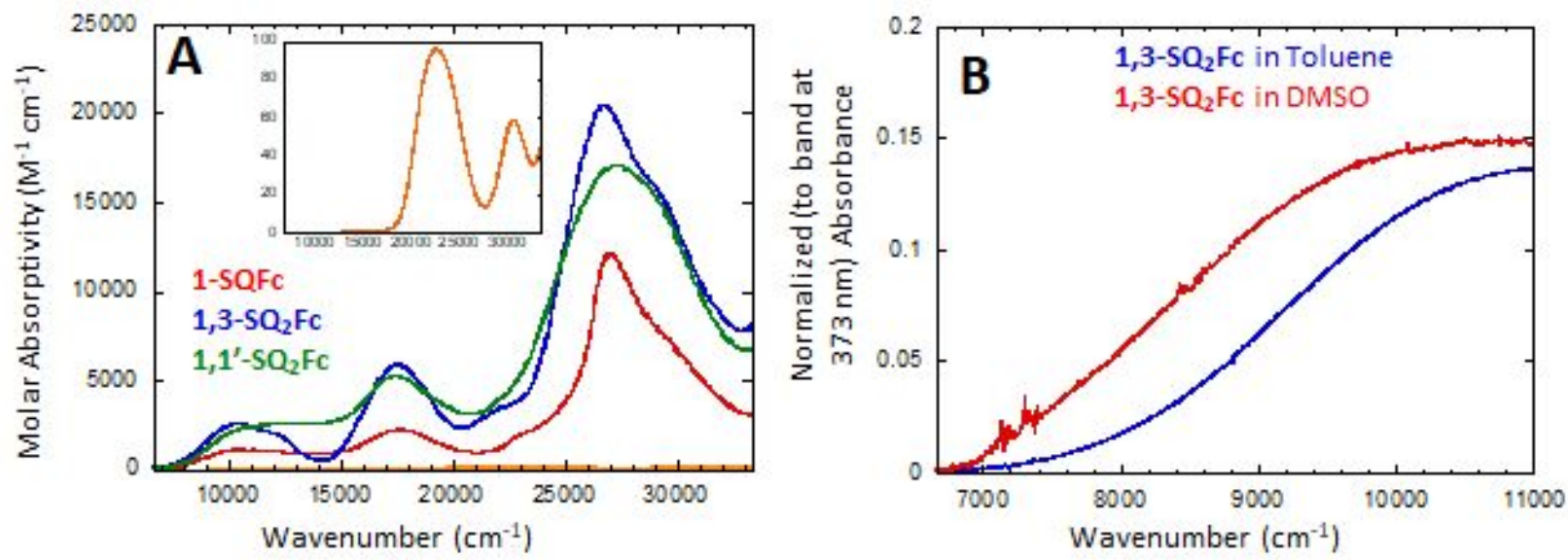

Figure S4. Electronic absorption spectra of (A) 1-SQFc, 1,3-SQ $\mathbf{S Q}_{2} \mathbf{F c}$ and 1,1'-SQ $\mathbf{F c}$. Inset: expanded view of ferrocene transitions. (B) comparison of $\mathbf{1 , 3 - S Q _ { 2 }} \mathbf{F c}$ spectral feature at $10000 \mathrm{~cm}^{-1}$ in DMSO and toluene.

Electrochemistry. SQ and ferrocene compounds are redox-active and Figure S5 shows the cyclic voltammogram of 1-SQFc. As expected, there are three distinct waves that correspond to the Cat $/ \mathrm{SQ}, \mathrm{Fc} / \mathrm{Fc}^{+}$and $\mathrm{SQ} / \mathrm{BQ}$ couples which appear at ca. $-0.9,0.0$ and $+0.4 \mathrm{~V}$, respectively vs. $\mathrm{Fc} / \mathrm{Fc}+$ standard. All three waves are reversible given the equal peak currents for both oxidation and reduction waves. 

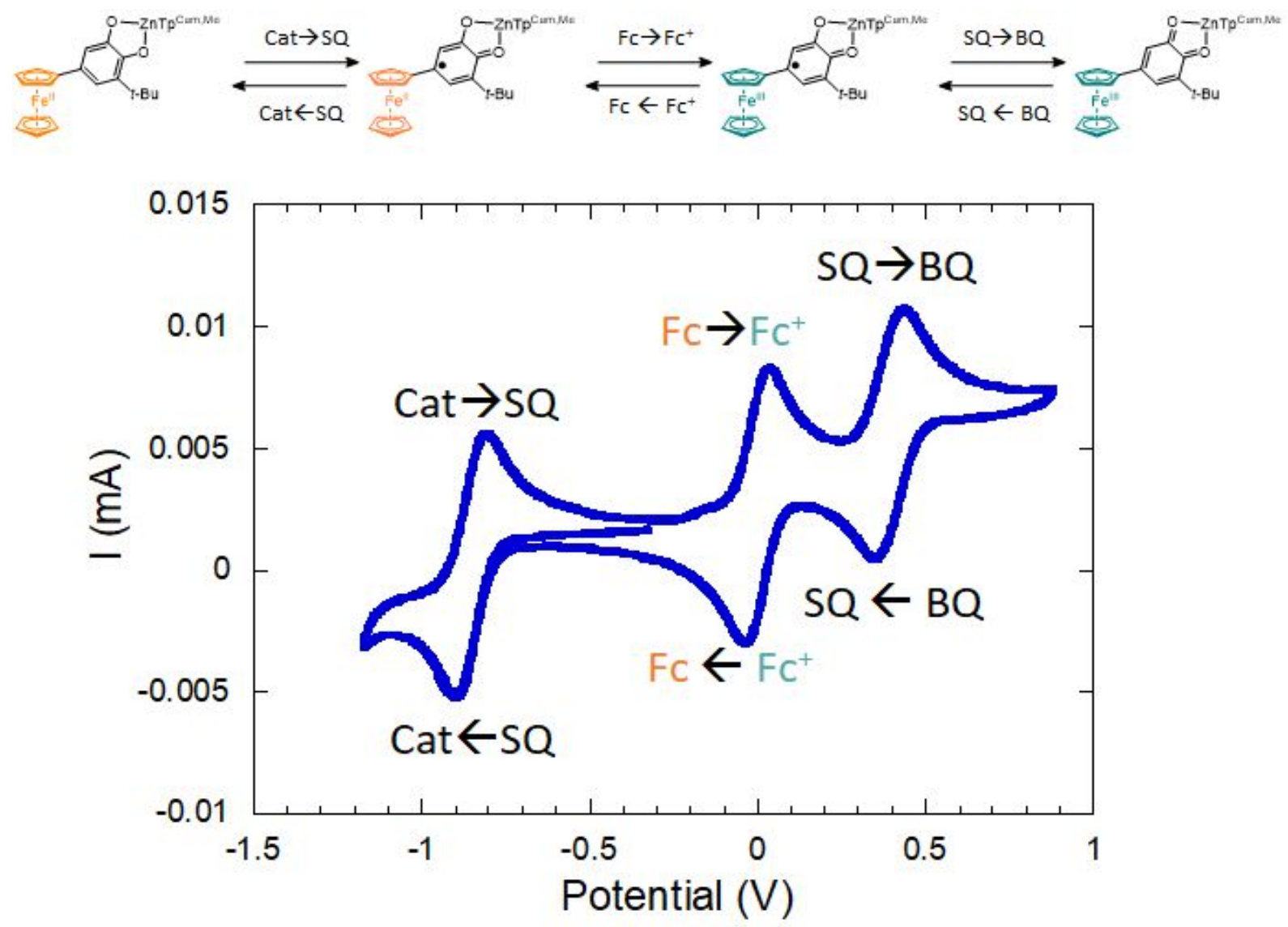

Figure S5. Cyclic voltammogram of 1-SQFe in $\mathrm{MeCN}$ with $0.1 \mathrm{M} \mathrm{Bu}_{4} \mathrm{NPF}_{6}$.

Figure S6 shows the CVs acquired for several symmetric SQ biradicals 1,3-SQ ${ }_{2} \mathrm{Fc}, \mathbf{1}_{1} \mathbf{1}^{\prime}-\mathrm{SQ}_{2} \mathrm{Fc}$, $\mathrm{SQ}_{\mathbf{2}}$ and 1,3-SQ $\mathbf{P h}$, along with the CVs of 1-SQFc, 1-MOM ${ }_{2}$ CatFc, and SQ-SQ (a closed-shell, quinoidal bis-dioxolene). The CV of 1-MOM $\mathbf{M}_{2}$ CatFc exhibits only the 1,3-diaryl-substituted Fc/Fc ${ }^{+}$ couple. Of particular note is the dramatically attenuated cathodic and anodic peak currents and less reversible redox couples for $\mathbf{1 , 3 - S Q _ { 2 }} \mathbf{F c}, \mathbf{1 , 1}-\mathbf{S Q}_{2} \mathbf{F c}, \mathbf{S Q}_{2}$, and $\mathbf{1 , 3 - S Q _ { 2 }} \mathbf{P h}$. 


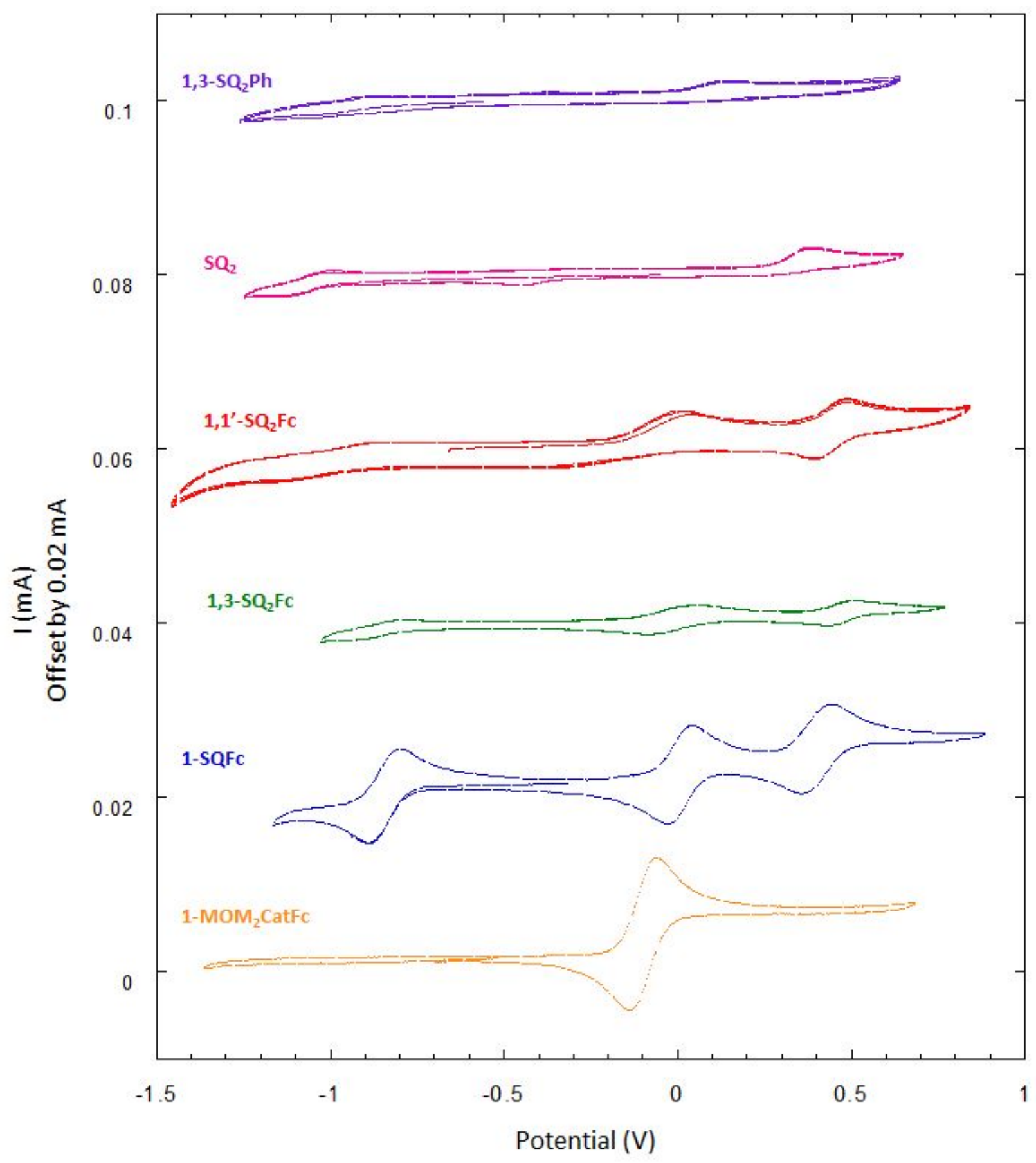

Figure S6. Cyclic voltammogram of 1,3-SQ ${ }_{2} \mathrm{Ph}, \mathrm{SQ}_{2}, 1,3-\mathrm{SQ}_{2} \mathrm{Fc}, 1,{ }^{\prime}-\mathrm{SQ}_{2} \mathrm{Fc}, 1-\mathrm{SQFe}$ and 1-MOM${ }_{2} \mathrm{CatFc}$ in $\mathrm{MeCN}$ with $0.1 \mathrm{M} \mathrm{Bu}_{4} \mathrm{NPF}_{6}$. 
Our explanation for the shapes of the redox waves in the biradicals is illustrated using space-filling models shown in Figure $\mathrm{S7}$. While we use the $\left[\mathrm{Tp}^{\mathrm{Cum}, \mathrm{Me}}\right]^{-}$ligand because it provides steric bulk to insulate our biradicals from each for magnetic studies, their steric bulk limits access of the redox-active SQ and Fc groups to the electrode surface. This results dramatic attenuation of heterogeneous electron transfer kinetics ${ }^{1}$ compared to 1-SQFc.
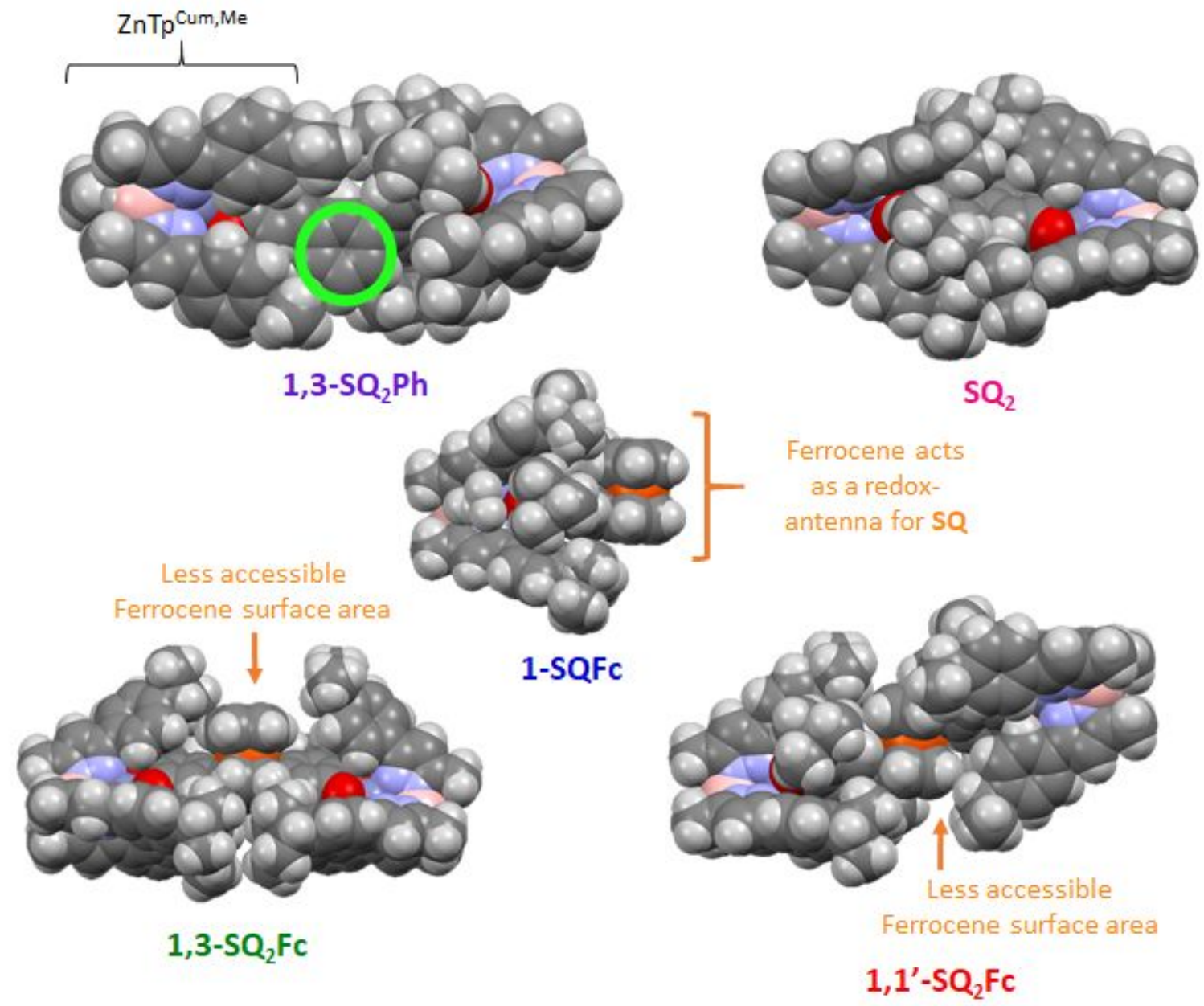

Figure $S 7$. Space-filling models from the crystal structures of $1,3-\mathrm{SQ}_{2} \mathrm{Ph}, \mathrm{SQ}_{2}, \mathbf{1}_{3}-\mathrm{SQ}_{2} \mathrm{Fc}, \mathbf{1}_{1} \mathbf{1}^{\prime}-\mathrm{SQ} \mathbf{Q}_{2} \mathrm{Fc}, \mathrm{SQ}_{2}$, and 1-SQFc. The $\left(\mathrm{ZnTp}^{\mathrm{Cum}, \mathrm{Me}}\right)^{+}$ligands for each molecule are displayed horizontally. Red atoms are the oxygen atoms of the SQ. The green circle shows the six-carbon atoms of the phenyl ring bridge from 1,3$\mathrm{SQ}_{2} \mathbf{P h}$.

\section{Reference for Electrochemistry}

1) Gorman, C. B.; Smith, J. C.; Hager, M. W.; Parkhurst, B. L.; Sierzputowska-Gracz, H.; Haney, C. A. Molecular Structure-Property Relationships for Electron-Transfer Rate Attenuation in RedoxActive Core Dendrimers. J. Am. Chem. Soc. 1999, 121 (43), 9958-9966. 
Electron Paramagnetic Resonance. EPR spectra were recorded on a Brüker ELEXSYS-II E500 CW EPR spectrometer with low temperature capabilities. Samples ca. $2 \mathrm{mM}$ in biradical (frozen solution experiments) were prepared in freshly distilled 2-methyl-tetrahydrofuran or toluene, degassed, and the spectra collected in quartz EPR tubes.

The isotropic room temperature spectrum of 1-SQFc in 2-MTHF is shown in Figure S6A. The spectrum was fit with EasySpin to a multiplet consisting of four proton hyperfine coupling constants and $g=2.0068$ (DPPH reference). Two of the hyperfine coupling constants correspond to two inequivalent protons: $a_{H 1}=2.13 \mathrm{G}$ and $a_{H 2}=0.62 \mathrm{G}$; and the other two correspond to two sets of two equivalent protons: $a_{H 3}=0.78 \mathrm{G}$ and $a_{H 4}=0.37 \mathrm{G}$. The top-down view of 1-SQFc in Figure S8A shows that the single inequivalent proton hyperfine coupling constants; $a_{H 1}$ and $a_{H 2}$, correspond to the inequivalent protons on the SQ ring and the two sets of two equivalent proton hyperfine coupling constants; $a_{H 3}$ and $a_{H 4}$, correspond to the two sets of equivalent protons on the one $\mathrm{Cp}$ ring which indicates delocalization of the radical into the $\pi$ system of the Cp ring. Figure S6B shows the powder spectrum of 1-SQFc in 2-MTHF at 110K and the $g$-tensors determined by simulation with EasySpin are $\mathrm{g}_{\mathrm{xx}}=2.0024, \mathrm{~g}_{\mathrm{yy}}=2.0136, \mathrm{~g}_{\mathrm{zz}}=$ 2.0045. The g-values are relative and were not measured by comparison to a standard.

Surprisingly, neither 1,3-SQ ${ }_{2}$ Fc nor 1,1'-SQ $\mathbf{1}_{2}$ Fc exhibited EPR spectra in frozen solvent at $100 \mathrm{~K}$. Further study of the EPR spectroscopy of these compounds will be the focus of a future study.
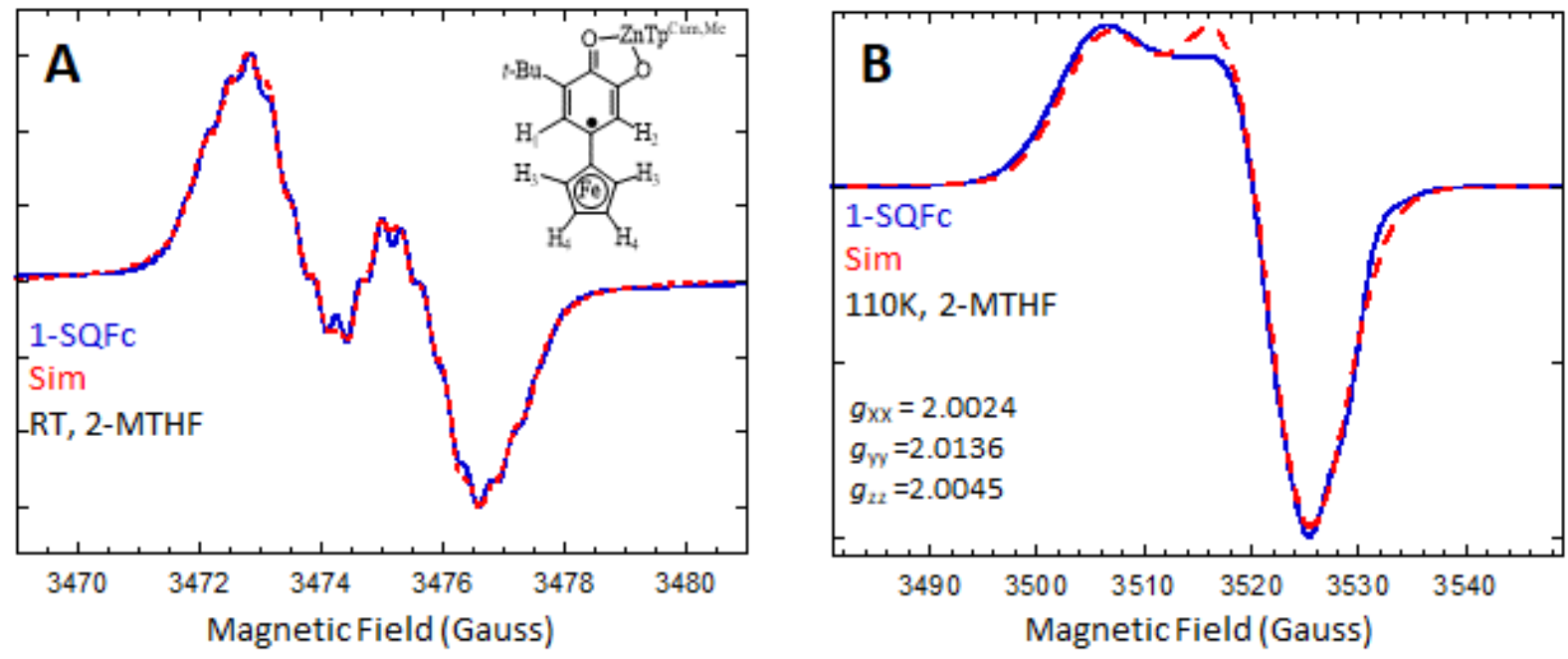

Figure S8. A) Room temperature isotropic spectrum of 1-SQFc in 2-MTHF. B) 110K powder spectrum of 1SQFc. Simulations were executed using Easyspin. ${ }^{\mathrm{TM}}$

The lack of triplet powder EPR spectra for both 1,3-SQ ${ }_{2} \mathbf{F c}$ and $1, \mathbf{1}^{\prime}-\mathrm{SQ}_{2} \mathrm{Fc}$ is indeed intriguing. Our observations are:

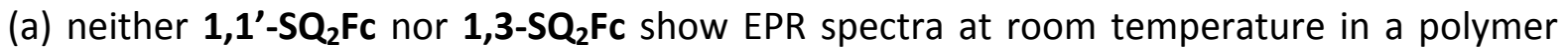
matrix, or at $100 \mathrm{~K}$ in a solvent glass (2-methyltetrahydrofuran). This finding is unique to Fcbridged biradicals as all other bis-semiquinone complexes prepared by us ( 2 dozen biradicals over $\sim 25$ years) show powder spectra complete with fine structure (allowing for zero-field splitting parameter determination by simulation) - even those with stronger antiferromagnetic coupling; 
(b) the monoradical complex, 1-SQ-Fc shows a "normal" fluid solution spectrum with proton hyperfine, and does not exhibit a power dependence suggesting slow relaxation;

(c) ferrocene with two nitronylnitroxide radicals (one on each $\mathrm{Cp}$ ring, $\mathbf{1 , 1} \mathbf{1}^{\prime}-\mathbf{N N}_{\mathbf{2}} \mathbf{F c}$ ) shows a "normal" organic triplet powder EPR spectrum complete with zero field splitting and anisotropic hyperfine ${ }^{1}$;

(d) There are no other ferrocene bridged biradicals in the literature with two radicals attached to the same $\mathrm{Cp}$ ring, and no ferrocene species in the literature with delocalized radicals attached to either $\mathrm{Cp}$ ring (nitronylnitroxide ${ }^{1}$ and verdazyl ${ }^{2}$ are connected to $\mathrm{Fc}$ at nodal carbons of the radicals, and percholotriphenylmethyls ${ }^{3}$ are sterically prevented from extensive delocalization).

Thus, our current hypothesis is that there is Fc $\mathrm{S}$ SQ charge transfer (CT) character in the ground state that results in a triplet zero-field splitting that is greater than the microwave quantum at $X$ band $\left(0.3 \mathrm{~cm}^{-1}\right)$. This hypothesis is supported by the following:

a) Our cyclic voltametric results show that the SQ/CAT couple is less than $1 \mathrm{~V}$ negative of the $\mathrm{Fc} / \mathrm{Fc}^{+}$couple suggesting that the $\mathrm{CT}$ excited state would be very low in energy $(1 \mathrm{~V}=\sim 8100$ $\mathrm{cm}^{-1}$ ), making it energetically viable for mixing with the ground state. We note that the electronic absorption spectra of all SQ-Fc complexes show a band (that shifts with solvent polarity) with an origin at $8000 \mathrm{~cm}^{-1}$ that is consistent with a Fc $\mathrm{SQQ}$ CT band (Figure S4B).

b) The corresponding CT state in $\mathbf{1}, \mathbf{1}^{\prime}-\mathbf{N N}_{\mathbf{2}} \mathbf{F c}$ would be over $1 \mathrm{~V}$ higher in energy as the reduction of $\mathrm{NN}$ radicals is $\sim 2 \mathrm{~V}$ negative of the $\mathrm{Fc} / \mathrm{Fc}^{+}$couple. As such, this $\mathrm{CT}$ state would not make a large contribution to the ground state electronic structure, and $\mathbf{1 , 1} \mathbf{1}^{\prime}-\mathbf{N N}_{\mathbf{2}} \mathbf{F c}$ therefore exhibits a "normal" powder triplet spectrum as reported by Veciana, et al. (and cited by us).

c) If the CAT- $\mathrm{Fc}^{+}-\mathrm{SQ} \mathrm{CT}$ excited state mixes into the ground states of $\mathbf{1 , 3 - S Q _ { 2 }} \mathbf{F c}$ and $\mathbf{1 , 1}$ '$\mathrm{SQ}_{2} \mathrm{Fc}$, it will affect both the magnetic exchange coupling as well as the zero-field splitting parameters of the ground state.

We feel that a detailed spectroscopic and computational study is required to fully understand the EPR spectroscopy and any superexchange mechanism involving a CAT-Fc+-SQ CT excited state, and that such a study is beyond the scope of the present manuscript.

\section{References for EPR}

1) Transmission of Magnetic Interactions through an Organometallic Coupler: A Novel Family of Metallocene-Substituted alpha-Nitronyl Aminoxyl Radicals," Jürgens, O.; Vidal-Gancedo, J.; Rovira, C.; Wurst, K.; Sporer, C.; Bildstein, B.; Schottenberger, H.; Jaitner, P.; Veciana, J. Inorg. Chem. 1998, 37, 4547-4558.

2) Hicks, et al. J. Am. Chem. Soc. 2006, 128, 690-1 (no powder spectrum published).

3) "Ferrocene Substituted Nitronyl Nitroxide and Imino Nitroxide Radicals. Synthesis, X-Ray Structure and Magnetic Properties," Sporer, C.; Ruiz-Molina, D.; Wurst, K.; Kopacka, H.; Veciana, J. J. Organomet. Chem. 2001, 637-639, 251-257 (no powder spectrum published, but text gives ZFS parameters). 
Magnetic Susceptibility. Magnetic susceptibility measurements were collected on a Quantum Design MPMS-XL7 SQUID magnetometer with an applied field of 0.7 T. A crystalline sample ( 20 $\mathrm{mg}$ ) was loaded into a gel cap/straw sample holder and mounted to the sample rod with Kapton tape for variable temperature measurements. Raw data were corrected with Pascal's constants as a first approximation for molecular diamagnetism followed by a straight line correction to all data for diamagnetic response of sample container where the slope of the line represents the residual diamagnetic correction. The Magnetic susceptibility data were fit using a fieldindependent van Vleck expression, $\chi_{\text {eff }} \mathrm{T}=[\chi /(1-\vartheta \chi)] T$, where $\vartheta=\frac{2 z J_{\text {inter }}^{\prime}}{N g^{2} \beta^{2}}$, and $\chi=\frac{0.75 g^{2}}{3+\exp \left(\frac{-2 J_{S Q B N N}}{0.695 \cdot T}\right)^{\prime}}$ and $J_{\text {SQNN }}$ is the SQ-Bridge-NN magnetic exchange parameter. ${ }^{1}$ The origin of $z J^{\prime}$ inter may be zerofield splitting, intermolecular interactions, saturation effects, or some combination of all three. ${ }^{1-2}$ In our data, the effects of $\mathrm{Z}^{\prime}{ }_{\text {inter }}$ are negligible compared to $J_{S Q-B-N N}$, and varying results in $10-15 \%$ changes in $J_{S Q-B-N N}$, which is insufficient to alter either our discussion or conclusions. In fact, by omitting the $\chi_{\text {para }} \bullet T$ data points below $10 \mathrm{~K}$, the data can be fit adequately without the $z J_{\text {inter }}^{\prime}$ term. Typically, the small deviation of the $g$-values (as a fit parameter) from the expected spin-only value of $\sim 2.00$ can be the result of minute ( $1 \%)$ weighing errors. We note that excellent fits required no "J-strain," suggesting that thermal (de)population of vibrational/torsional levels have no effect on the magnetic data, in accord with our published results on other SQ-Bridge-NN molecules.

\section{References for Magnetic Susceptibility}

1) "Magnetochemistry - Advances in Theory and Experimentation," O'Connor, C. J. Prog. Inorg. Chem. 1982, 29, 203.

2) "Trends in Metal-Biradical Exchange Interaction for First-Row MII(Nitronyl NitroxideSemiquinone) Complexes," Shultz, D. A.; Vostrikova, K. E.; Bodnar, S. H.; Koo, H.-J.; Whangbo, M.H.; Kirk, M. L.; Depperman, E. C.; Kampf, J. W. J. Am. Chem. Soc. 2003, 125, 1607-1617. 


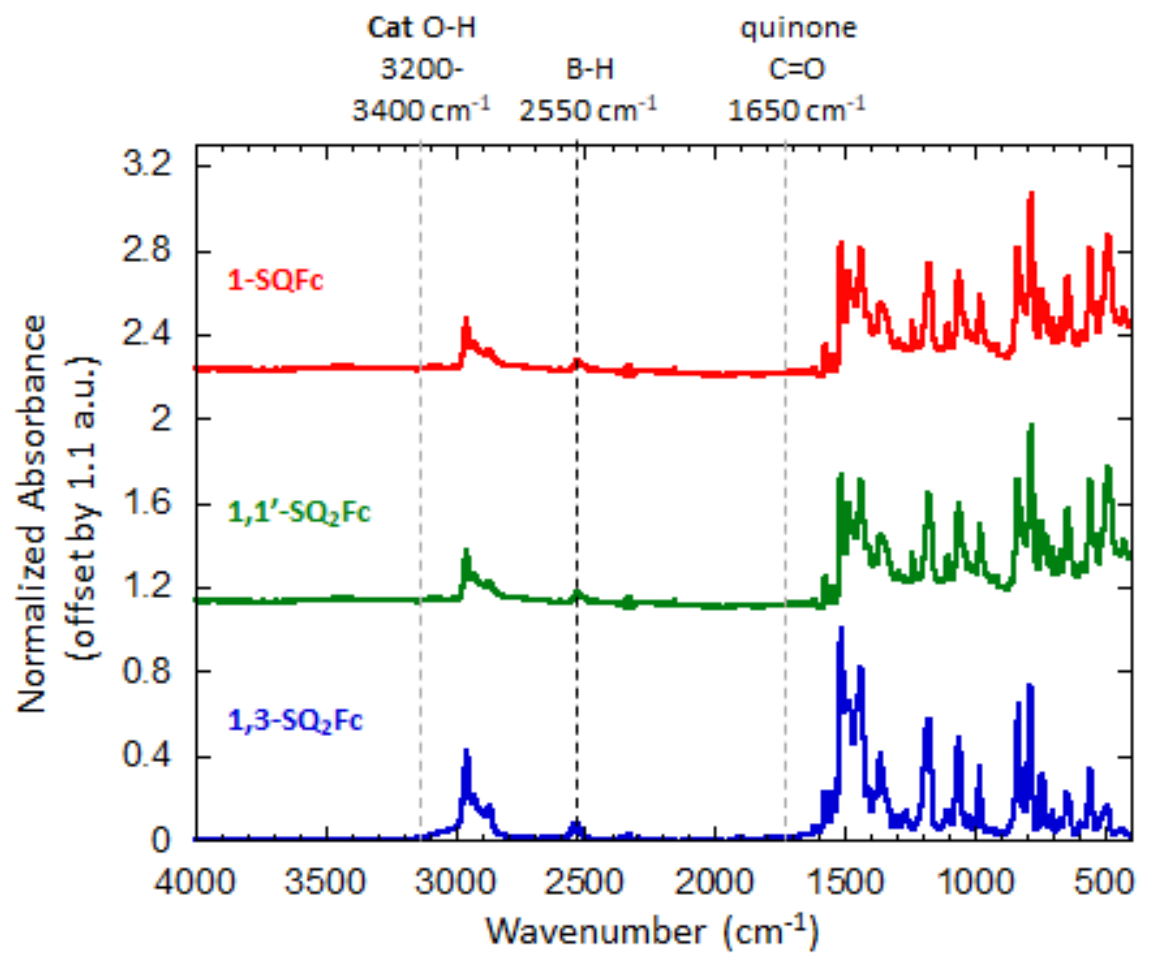

Figure S7. IR spectra of 1-SQFc, 1,1'-SQ $\mathbf{S Q}_{2} \mathbf{F c}$, and $1,3-\mathrm{SQ}_{2} \mathbf{F c}$ showing B-H stretches and no catechol or quinone impurities as would be indicated by the presence of $\mathrm{O}-\mathrm{H}$ or $\mathrm{C}=\mathrm{O}$ stretches. 


\section{NMR Spectra}

${ }^{1} \mathrm{H} \mathrm{NMR}, 400 \mathrm{MHz}, \mathrm{CDCl}_{3}$<smiles>COc1cc(-c2cc(-c3cc(OC)c(OC)c(C(C)(C)C)c3)cc(C(C)(C)C)c2)cc(OC)c1OC</smiles>

1,3-( $\left(\mathrm{MOM}_{2} \mathrm{Cat}\right)_{2} \mathrm{Fc}$

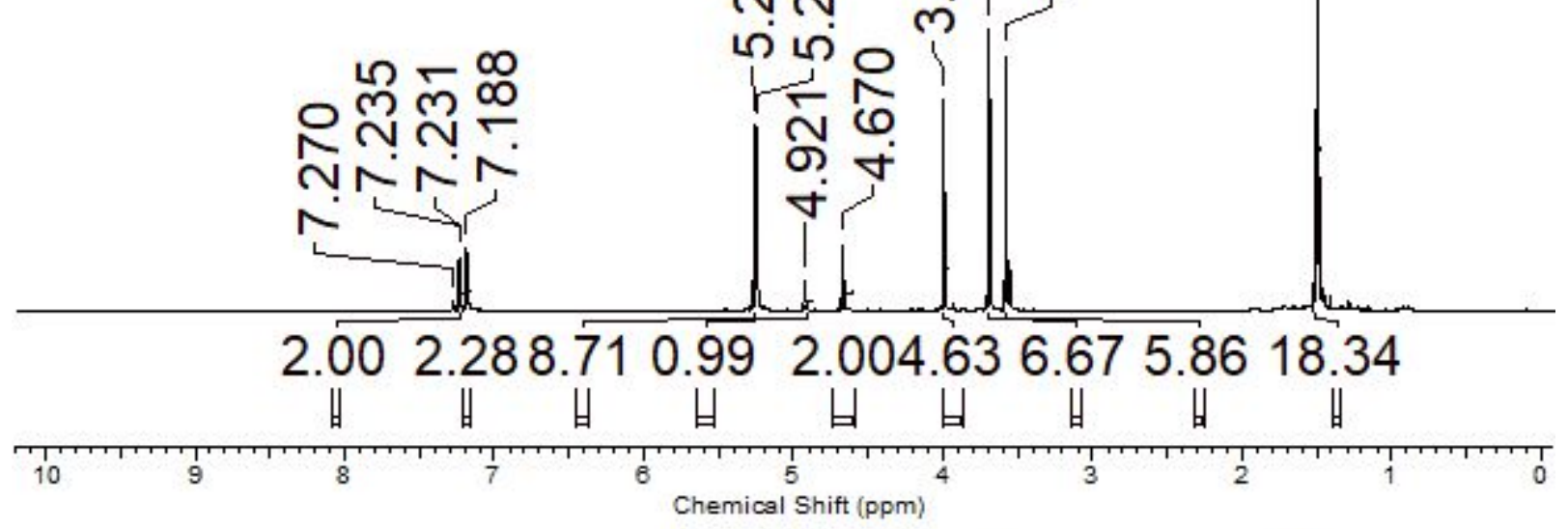

${ }^{13} \mathrm{C}\left\{{ }^{1} \mathrm{H}\right\}$ NMR, $101 \mathrm{MHz}, \mathrm{CDCl}_{3}$

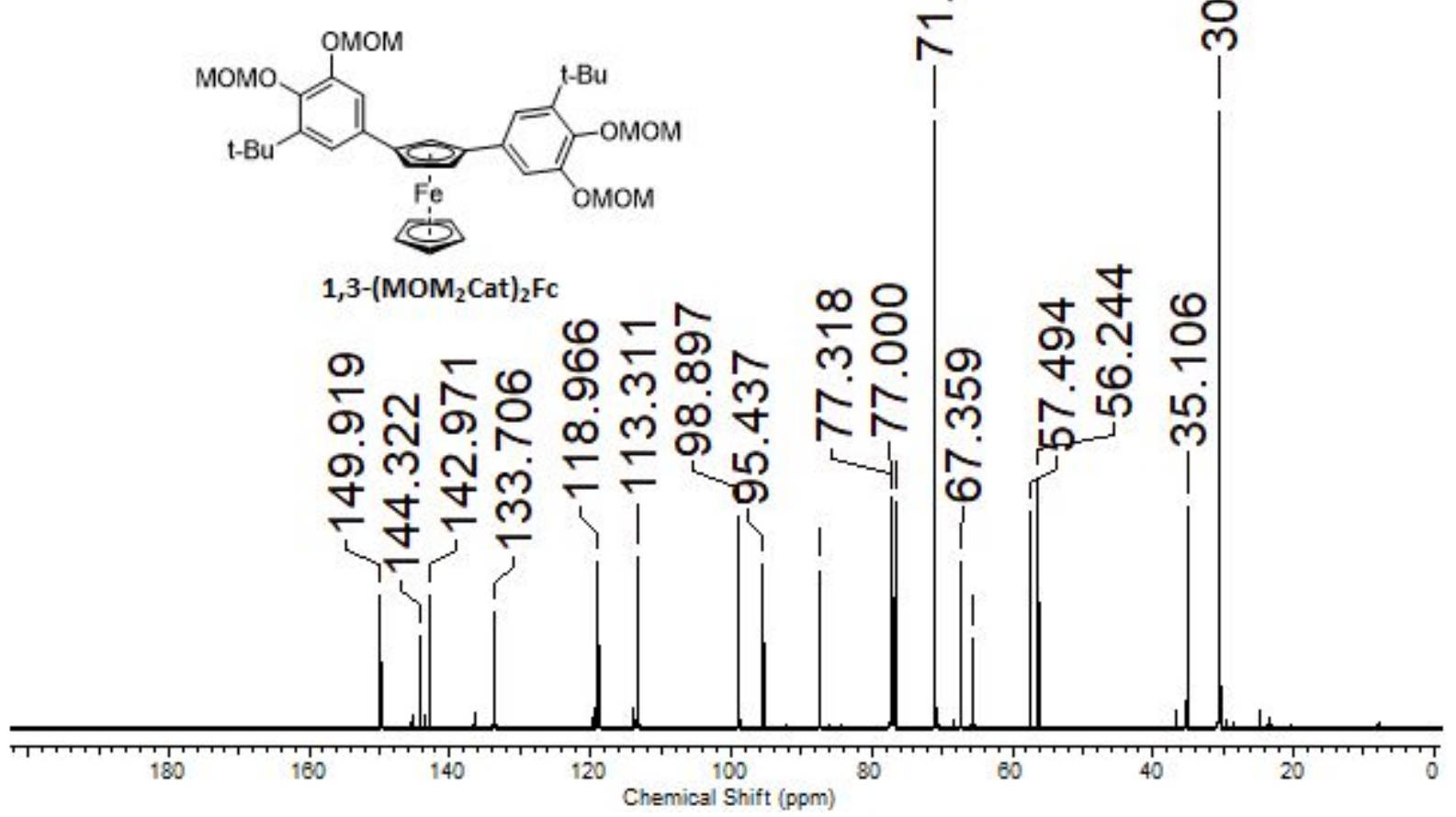



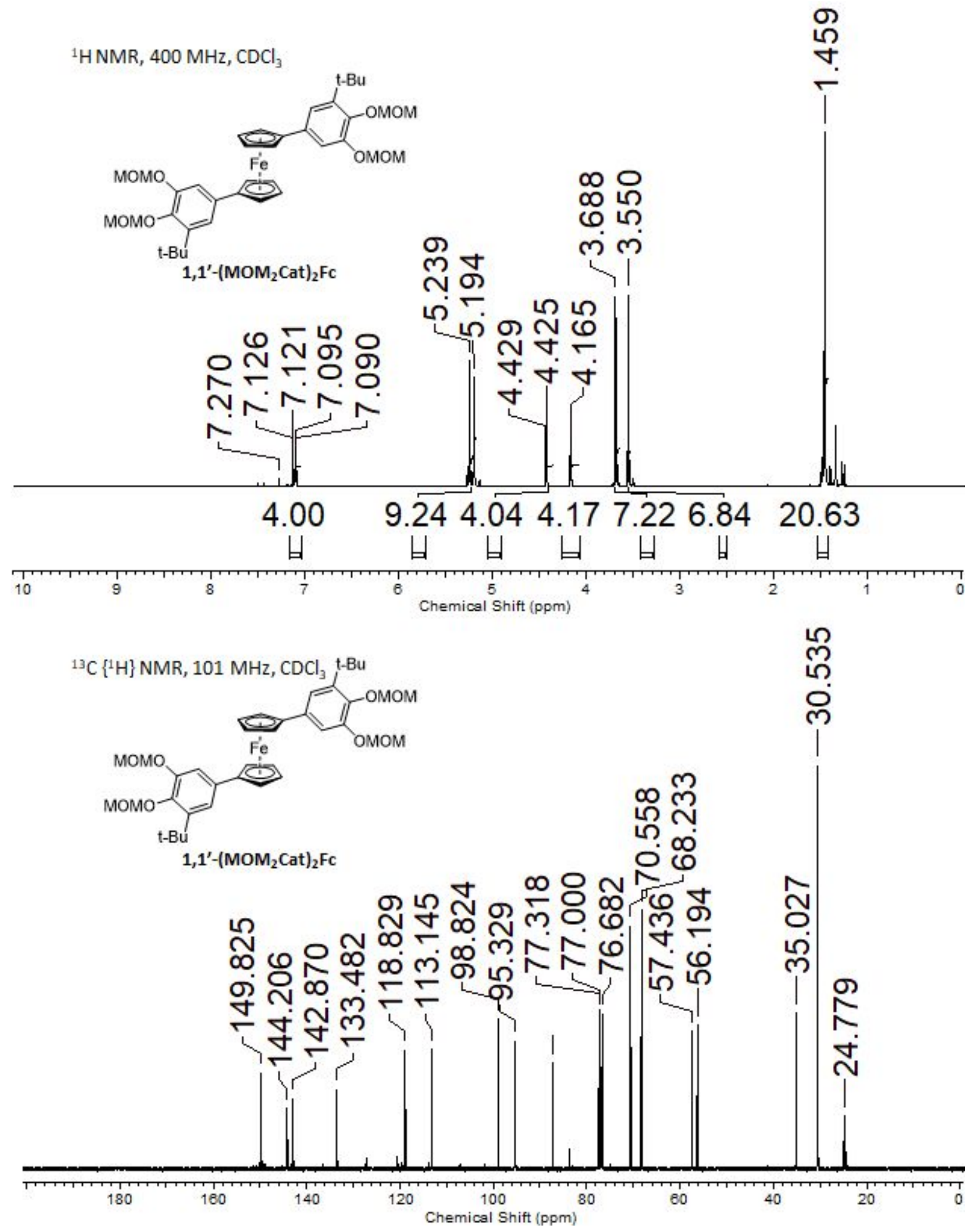


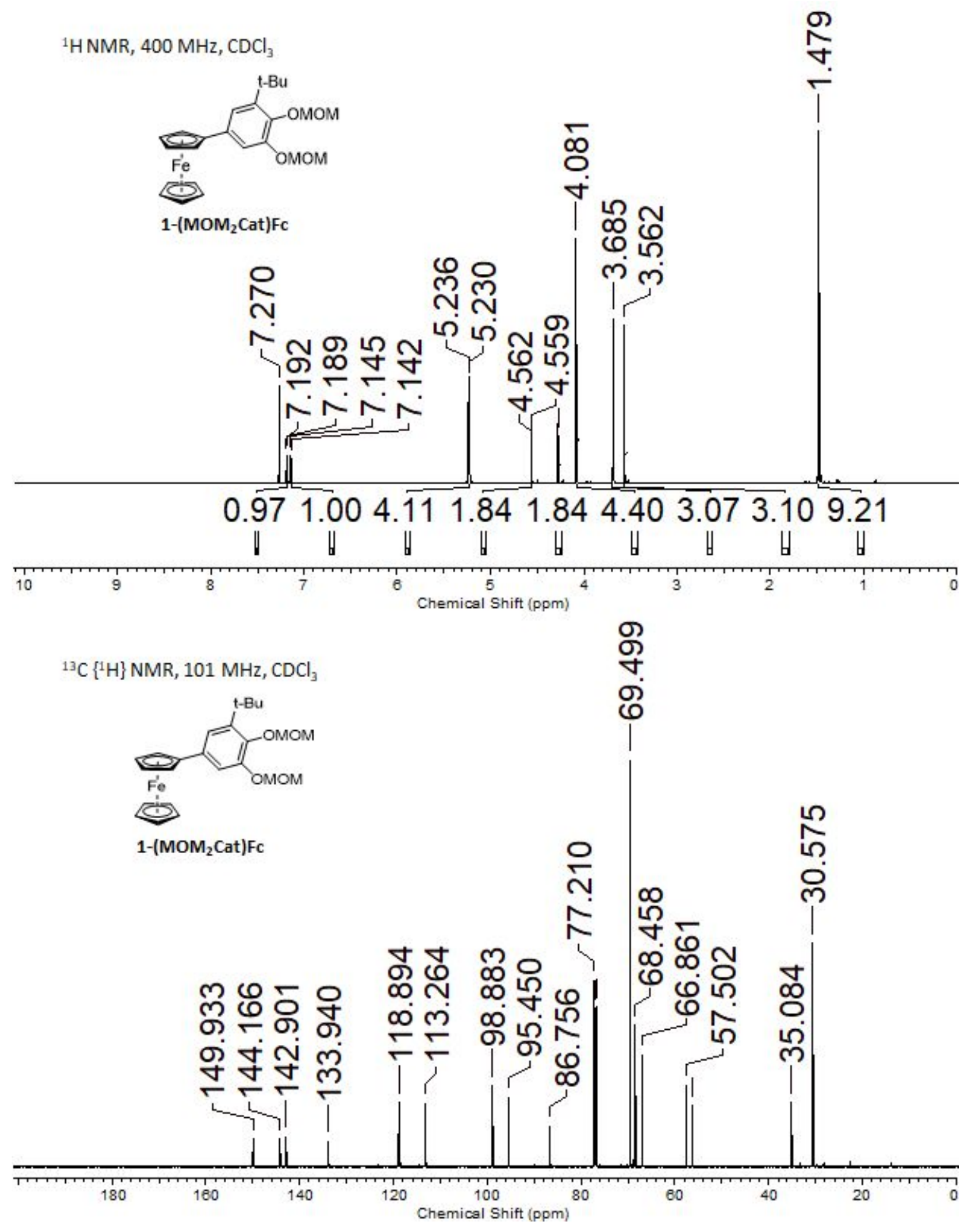




\section{HRMS}
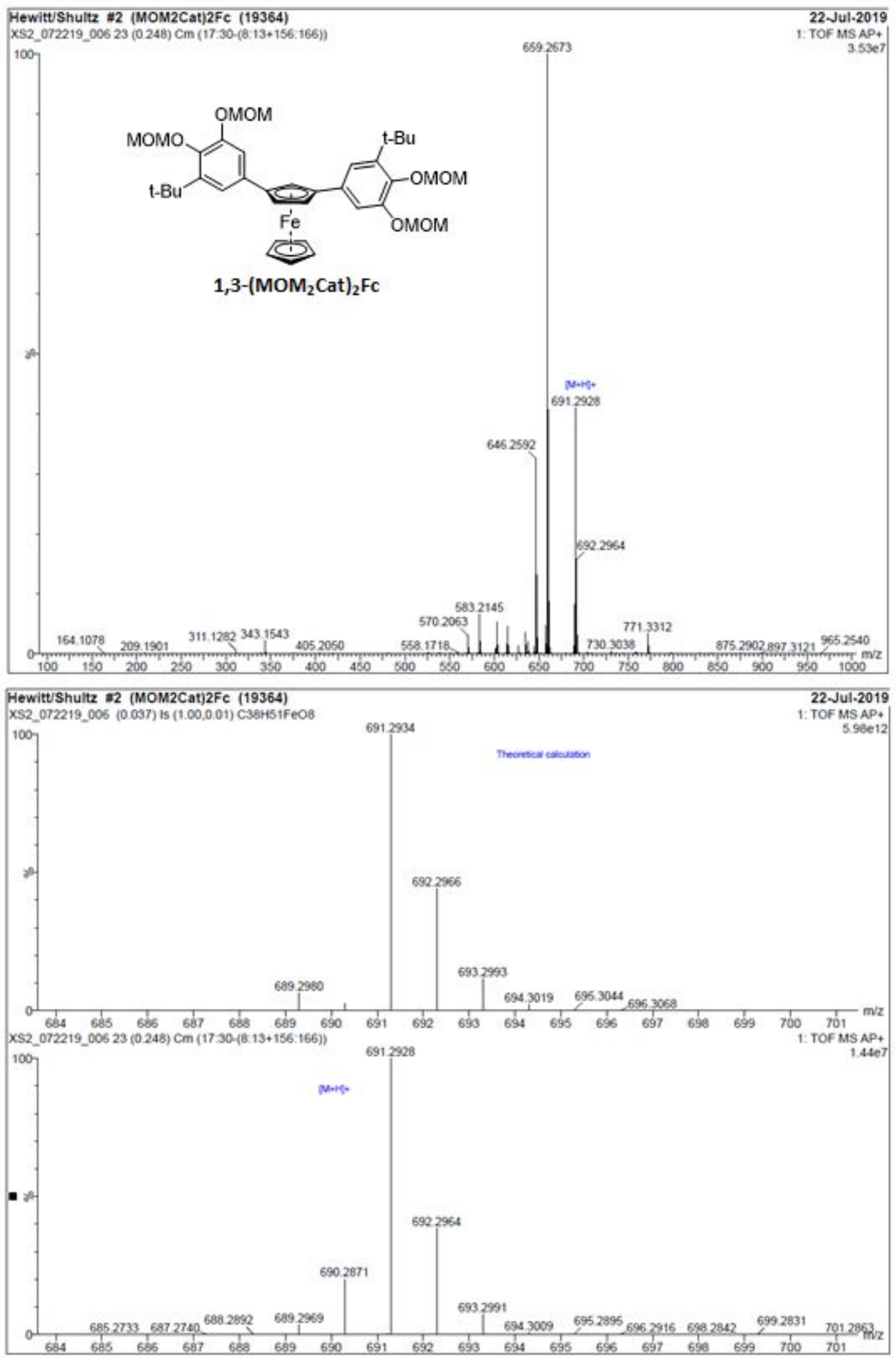


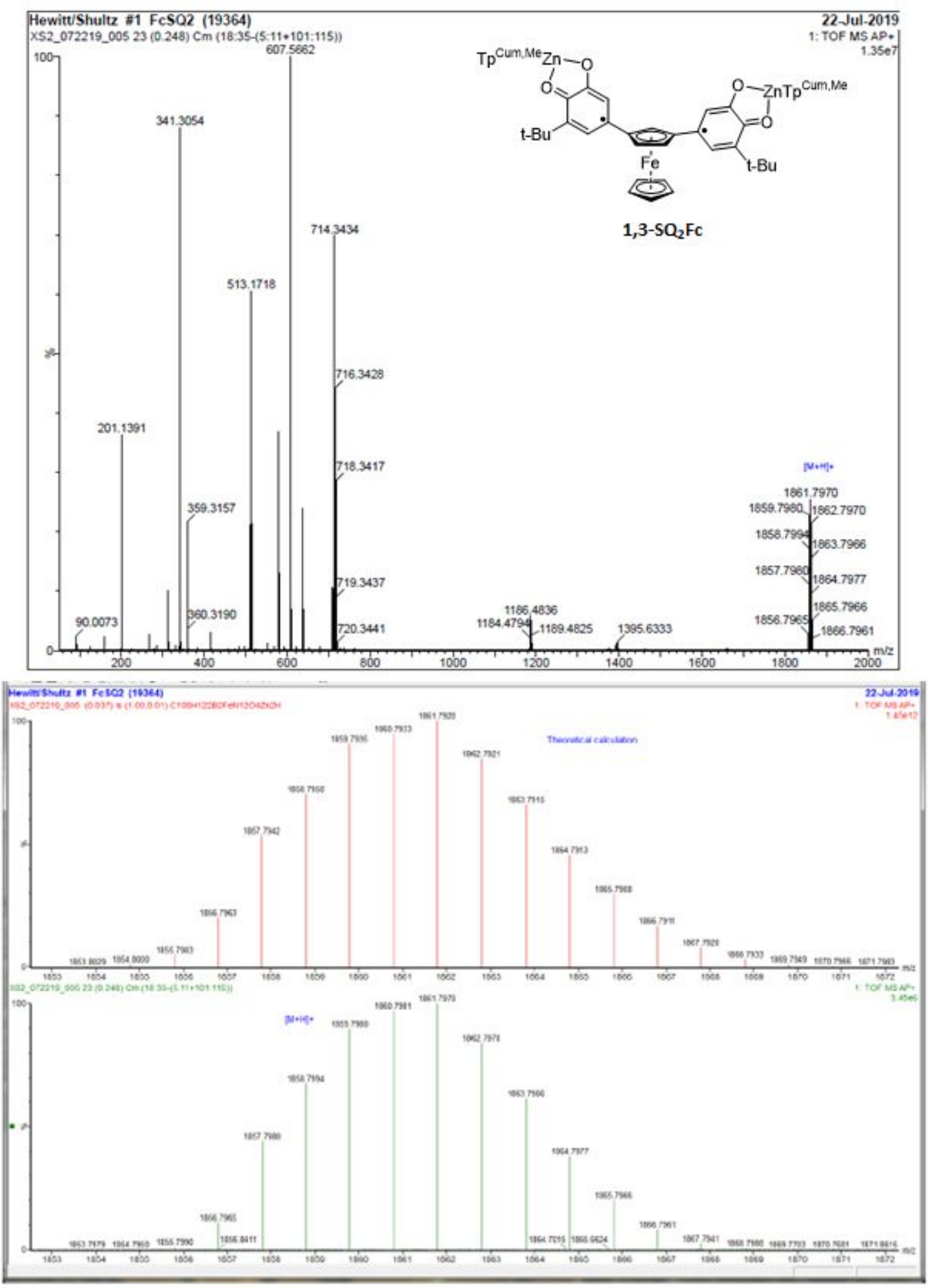



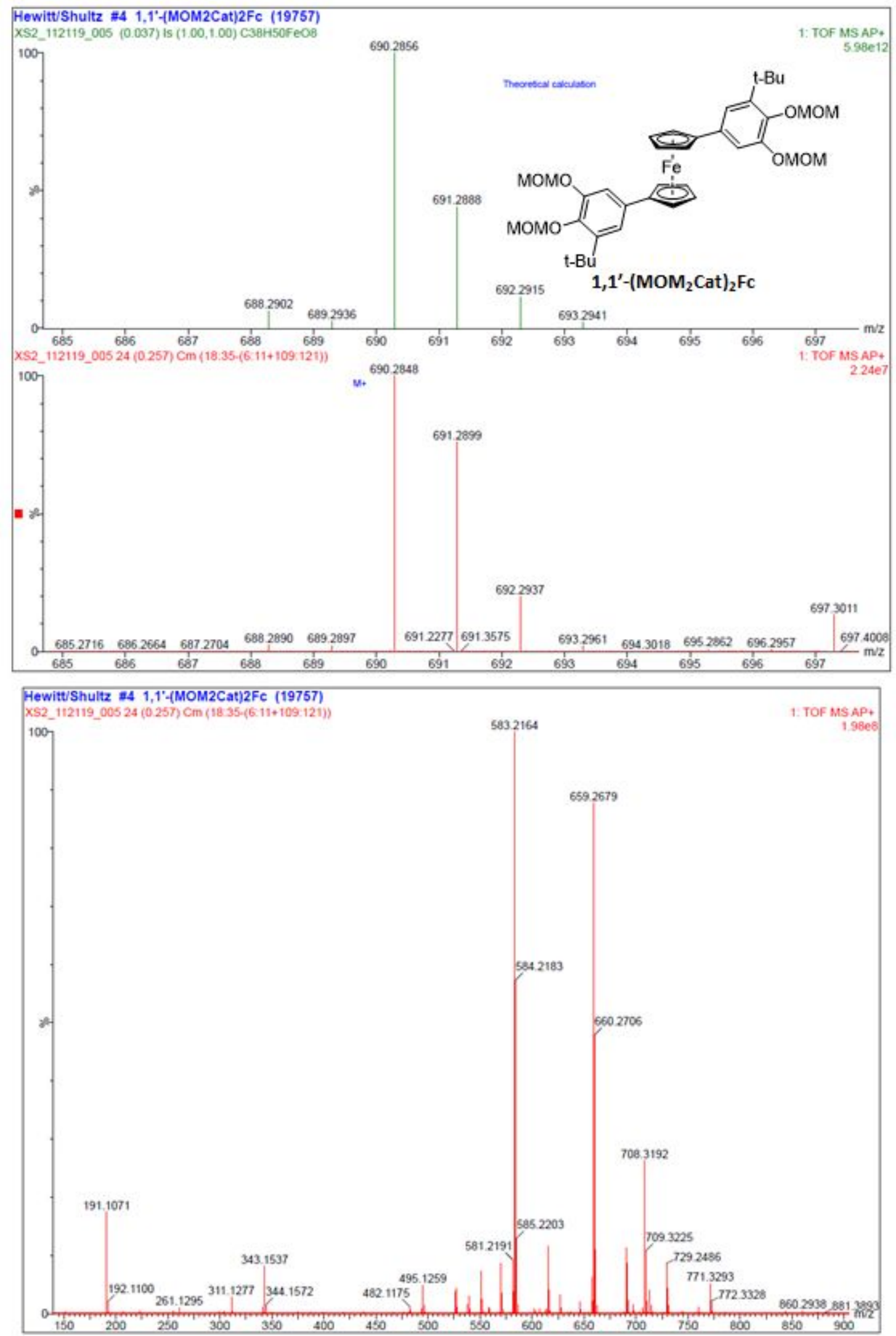

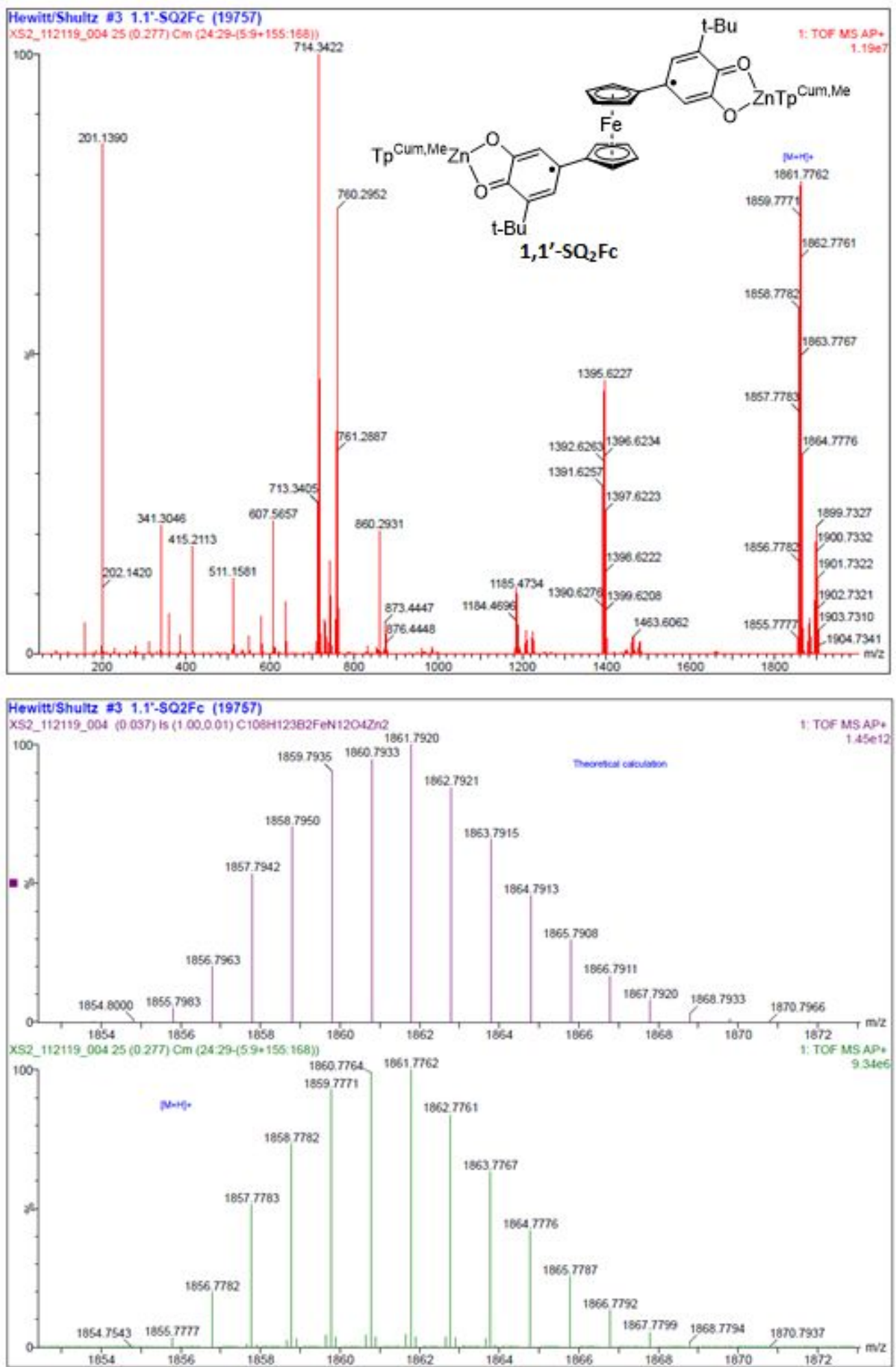

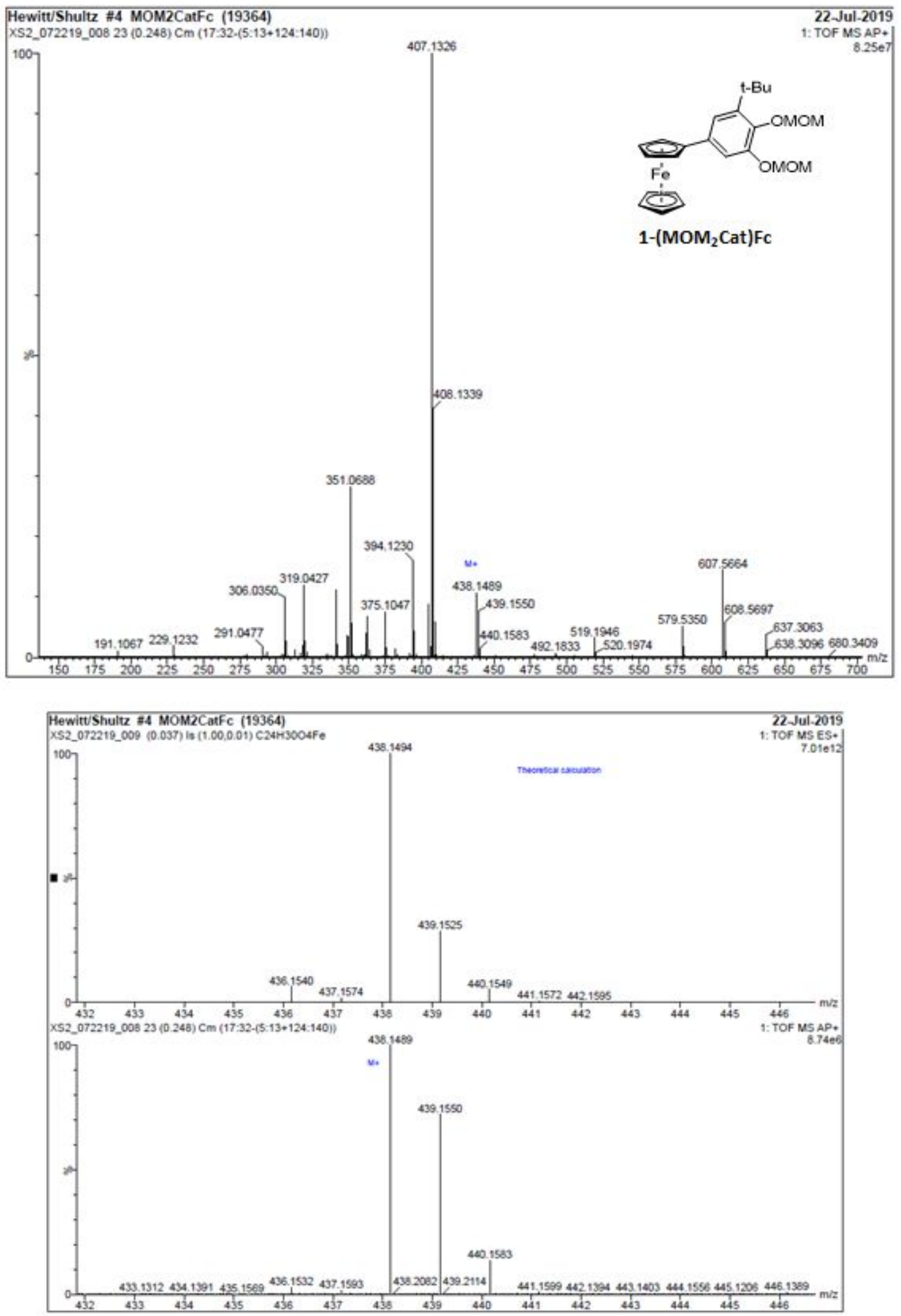


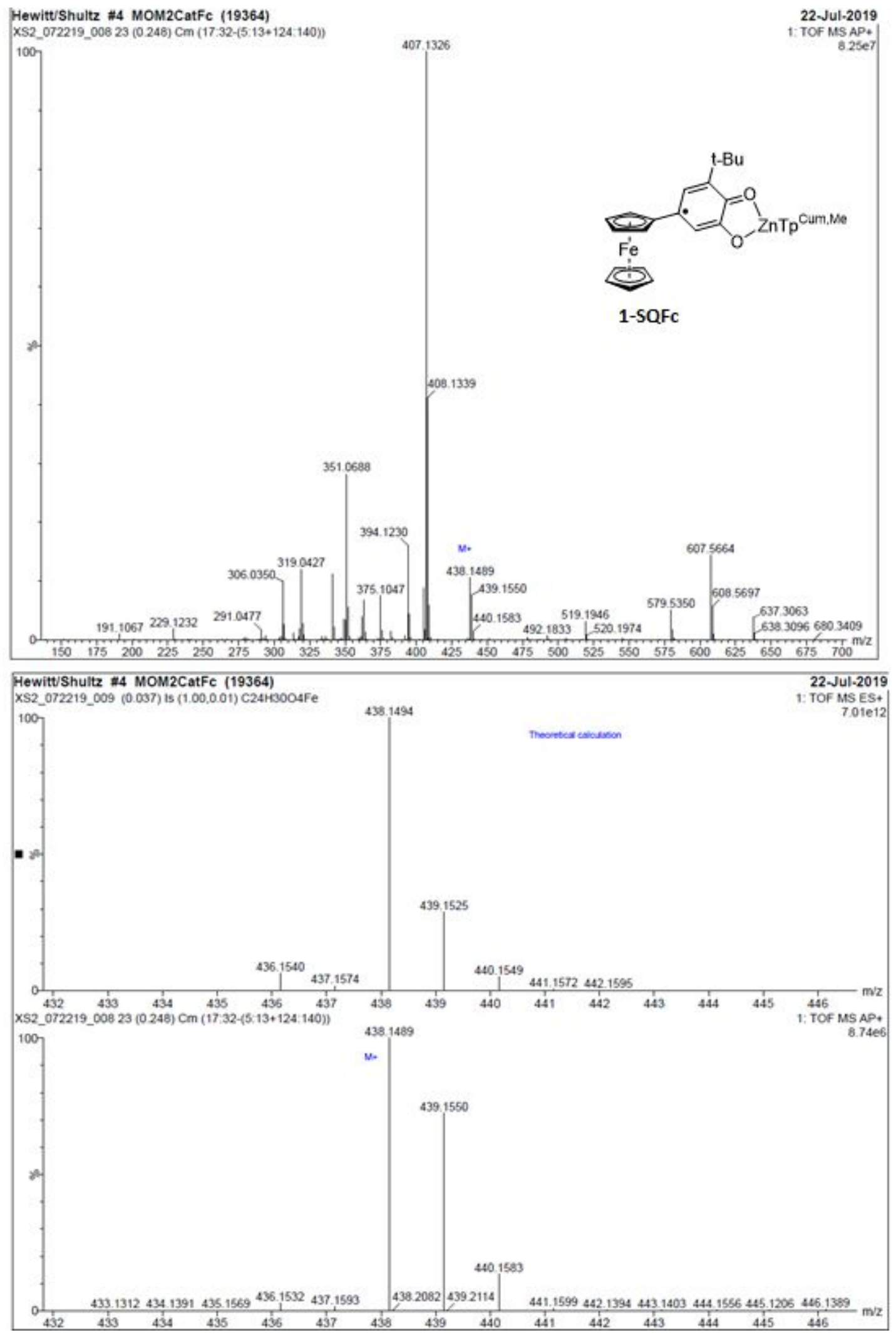

